Prepared in cooperation with

Red Nacional de Vigilancia Volcánica del Servicio Nacional de Geología y Minería de Chile

\title{
United States-Chile Binational Exchange for Volcanic Risk Reduction, 2015-Activities and Benefits
}

Circular 1432 
Cover. Chilean and American delegates on caldera rim of Chaitén Volcano, Chile, March 28, 2015. The steaming lava dome is in the background. (Photograph by Christopher Wills, California Geological Survey.) 


\section{United States-Chile Binational Exchange for Volcanic Risk Reduction, 2015- Activities and Benefits}

By Thomas C. Pierson, Margaret T. Mangan, Luis E. Lara Pulgar, and Álvaro Amigo Ramos

Prepared in cooperation with Red Nacional de Vigilancia Volcánica del Servicio Nacional de Geología y Minería de Chile

Circular 1432 


\title{
U.S. Department of the Interior \\ RYAN K. ZINKE, Secretary
}

\section{U.S. Geological Survey William H. Werkheiser, Acting Director}

\author{
U.S. Geological Survey, Reston, Virginia: 2017
}

For more information on the USGS - the Federal source for science about the Earth, its natural and living resources, natural hazards, and the environment-visit https://www.usgs.gov/ or call 1-888-ASK-USGS.

For an overview of USGS information products, including maps, imagery, and publications, visit https://store.usgs.gov.

Any use of trade, firm, or product names is for descriptive purposes only and does not imply endorsement by the U.S. Government.

Although this information product, for the most part, is in the public domain, it also may contain copyrighted materials as noted in the text. Permission to reproduce copyrighted items must be secured from the copyright owner.

Suggested citation:

Pierson, T.C., Mangan, M.T., Lara Pulgar, L.E., Amigo Ramos, Álvaro, 2017, United States-Chile binational exchange for volcanic risk reduction, 2015—Activities and benefits: U.S. Geological Survey Circular 1432, 43 p.,

https://doi.org/10.3133/cir1432.

\section{Library of Congress Cataloging-in-Publication Data}

Names: Pierson, Thomas C., author. | Red Nacional de Vigilancia Volcâanica (Chile) | Geological Survey (U.S.), issuing body.

Title: United States-Chile Binational Exchange for Volcanic Risk Reduction,

2015 : activities and benefit / by Thomas C. Pierson [and three others].

Other titles: U.S. Geological Survey circular ; 1432. 1067-084X

Description: Reston, Virginia : U.S. Geological Survey, 2017. | Series:

Circular, ISSN 1067-084X; 1432 |"Prepared in cooperation with Red

Nacional de Vigilancia Volcâanica del Servicio Nacional de Geologâia y

Minerâia de Chile." | Includes bibliographical references.

Identifiers: LCCN 2017033949| ISBN 9781411341555 | ISBN 1411341554

Subjects: LCSH: Binational Exchange for Volcanic Risk Reduction (Program) |

Volcanic hazard analysis--United States. | Volcanic hazard analysis--Chile.

Classification: LCC OE527.6 .P54 2017 | DDC 363.34/95--dc23 | SUDOC |

19.4/2:1432

LC record available at https://lccn.loc.gov/2017033949

ISSN 1067-084X (print)

ISSN 2330-5703 (online)

ISBN 978-1-4113-4155-5 


\section{United States-Chile Binational Exchange Delegates}

\section{U.S. delegates}

Mona Bontty, southern regional administrator

California Governor's Office of Emergency Services

Jeffrey Hinson, fire management officer Inyo National Forest, Mammoth Ranger District, U.S. Forest Service

Kristin Kirschner, park ranger

Yosemite National Park, National Park Service

Helen Lopez, assistant director/international liaison

Financial Accountability and Compliance Office, California Governor's Office of Emergency Services

Margaret Mangan, volcanologist/scientist-incharge

U.S. Geological Survey California Volcano Observatory

(Exchange coordinator-U.S.A.)

Ronald Martin, ranger operations supervisor

Lassen Volcanic National Park, National Park Service

Carolyn Napper, district ranger

Shasta McCloud Management Unit, Shasta-Trinity National Forest,

U.S. Forest Service

Thomas Pierson, research hydrologist

U.S. Geological Survey Cascades Volcano Observatory

(Exchange co-coordinator-U.S.A.)

Stuart Wilkinson, volcano monitoring network specialist

U.S. Geological Survey California Volcano Observatory

Christopher Wills, engineering geologist

California Geological Survey

Nathan Wood, research geographer

U.S. Geological Survey Western Geographic Science Center
Chilean delegates

Álvaro Amigo Ramos, volcanologist

Red Nacional de Vigilancia Volcánica, Servicio Nacional de Geología y Minería

(Exchange co-coordinator-Chile)

Mariela Chavarriga, Chilean national working as a risk-management specialist with Office of U.S. Foreign Disaster Assistance, U.S. Agency for International Development

Karem Cofré Orellana, chief of social services section

Gobernación de Palena

Gonzalo Hermosilla Pineda, geologist/scientist-in-charge

Observatorio Volcanológico de Coyhaique, Red Nacional de Vigilancia Volcánica, Servicio Nacional de Geología y Minería

Luis Lara Pulgar, volcanologist and chief

Red Nacional de Vigilancia Volcánica, Servicio Nacional de Geología y Minería de Chile

(Exchange coordinator-Chile)

Felipe Plaza Chacón, geographer

Centro de Alerta Temprana, Oficina Nacional de Emergencia

Pedro Vásquez Celedón, mayor

Municipalidad de Chaitén

Alejandro Vergés Castillo, regional director

Región de Los Lagos, Oficina Nacional de Emergencia

Carlos Zambrano Fernández, general manager Parque Pumalín 


\section{Contents}

United States-Chile Binational Exchange Delegates .......................................................................iii

Acronyms and Abbreviations.................................................................................................

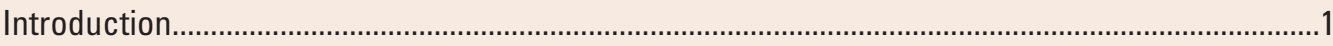

Past Volcanic Activity and Crisis-Response Challenges at Chaitén Volcano and

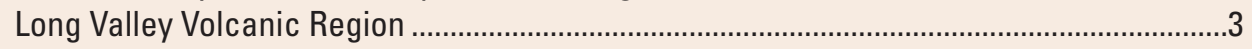

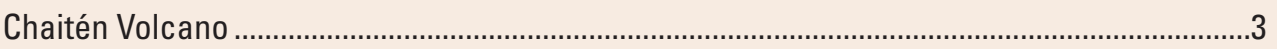

Long Valley Volcanic Region......................................................................................

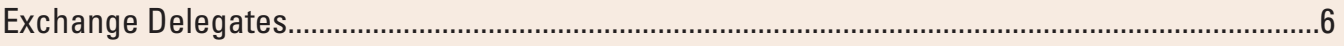

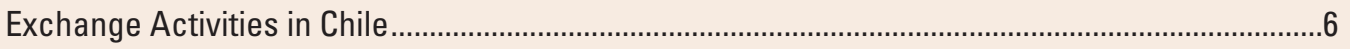

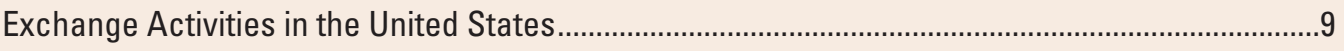

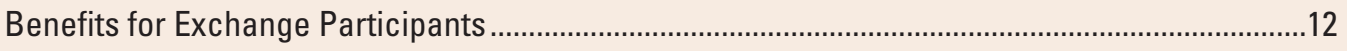

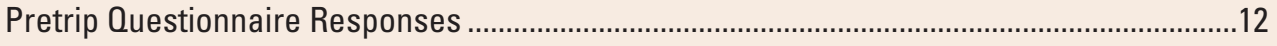

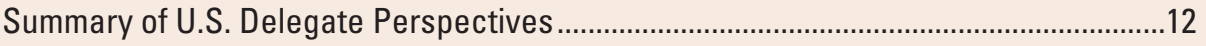

Summary of Chilean Delegate Perspectives...........................................................12

Posttrip Questionnaire Responses ....................................................................................13

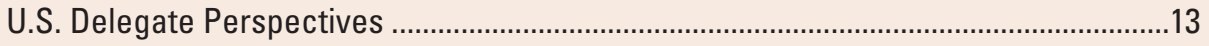

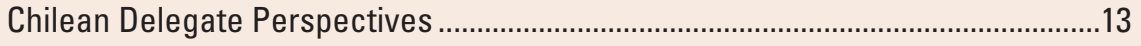

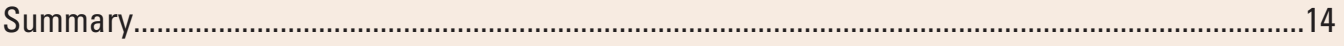

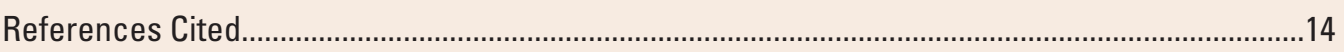

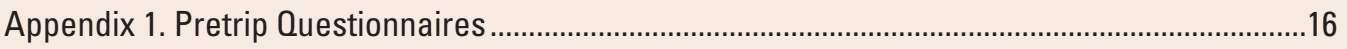

U.S. Delegate Responses to Chile Pretrip Questionnaire ......................................................16

Chilean Delegate Responses to California Pretrip Questionnaire................................................21

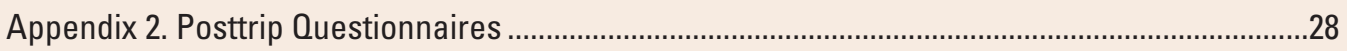

U.S. Delegate Responses to Chile Posttrip Questionnaire ......................................................28

Chilean Delegate Responses to California Posttrip Questionnaire ............................................35

\section{Figures}

1. Maps showing locations of the Long Valley volcanic region in California, U.S.A., and Chaitén Volcano region in Chile .

2. Photograph of an explosive eruptive pulse from Chaitén Volcano, Chile, viewed from town of Chaitén during the first week of its eruption in May 2008

3. Photograph taken June 6, 2008, showing damage to the town of Chaitén, Chile, caused by excessive sedimentation and flooding from the Chaitén River 
4. Photograph showing Long Valley Caldera, California, viewed from summit of Mammoth Mountain, a lava-dome complex built on the caldera rim

5. Photograph of a briefing to U.S. delegates at the National Seismological Center at the University of Chile.

6. Photograph of a briefing to U.S.-Chile-exchange participants on volcano monitoring in the southern Andes by the chief of seismic monitoring at Observatorio Volcanológico de Los Andes del Sur...

7. Photograph of U.S.-Chile-exchange participants examining deposits and damage caused by a lahar on March 3 during the 2015 eruption of Villarrica Volcano, Chile

8. Photograph showing presentation of U.S. Geological Survey volcano hazard posters to the Mayor of Pucón, Chile, by a U.S.-Chile exchange coordinator during the first meeting of officials after evacuation of the town during the March 2015 eruption of Villarrica Volcano.

9. Photograph showing juxtaposition of a recently built and currently occupied municipal building with the ruins of a partially buried (in 2008) and now decaying and unoccupied house in the town of Chaitén, Chile

10. Photograph of a briefing to U.S.-Chile-exchange participants on operational protocols and responsibilities of emergency managers at the Los Angeles County Emergency Operations Center

11. Photograph of a discussion among Chilean delegates on summit of Mammoth Mountain, California, with a view of Horseshoe Lake (a carbon dioxide $\left[\mathrm{CO}_{2}\right]$ gas hazard area) in the background

12. Photograph of U.S. Geological Survey (USGS) geologist explaining to U.S.-Chile-exchange participants USGS efforts to monitor and understand carbon dioxide $\left(\mathrm{CO}_{2}\right)$ gas release in the Long Valley Caldera, California.

13. Photograph of a U.S.-Chile exchange group discussion during overview of the Incident Command System, the National Incident Management System, and tabletop scenario exercises being presented by National Park Service rangers

14. Photograph of U.S.-Chile-exchange participants receiving an explanation of Yosemite National Park, California, access roads and visitor flow in order to understand National Park Service emergency-management and emergencyresponse philosophy, training protocols, and preparations for emergencies.

15. Photograph of U.S.-Chile-exchange participants, gathered on the shore of Mono Lake, California, receiving an explanation by a U.S. Geological Survey geologist of the eruptive history and hazards of the Mono-Inyo Craters 


\section{Acronyms and Abbreviations}

$\begin{array}{ll}\mathrm{ft} & \text { foot } \\ \mathrm{km} & \text { kilometer } \\ \mathrm{m} & \text { meter } \\ \text { Cal OES } & \text { California Governor's Office of Emergency Services } \\ \text { CGS } & \text { California Geological Survey } \\ \text { CERT } & \text { community emergency response team } \\ \text { CO } & \text { carbon dioxide } \\ \text { CONAF } & \text { Corporación Nacional Forestal [Chilean National Forest Corporation] } \\ \text { CVO } & \text { U.S. Geological Survey Cascades Volcano Observatory } \\ \text { EOC } & \text { emergency operations center } \\ \text { FEMA } & \text { Federal Emergency Management Agency } \\ \text { ICS } & \text { Incident Command System } \\ \text { NIMS } & \text { National Incident Management System } \\ \text { NPS } & \text { National Park Service } \\ \text { OFDA } & \text { Office of U.S. Foreign Disaster Assistance } \\ \text { ONEMI } & \text { Oficina Nacional de Emergencia [Chilean National Emergency Office] } \\ \text { OVDAS } & \text { Observatorio Volcanológico de Los Andes del Sur [Southern Andean Volcano } \\ \text { RNVV } & \text { Observatory] } \\ \text { SEMS } & \text { Red Nacional de Vigilancia Volcánica [Chilean National Volcano Monitoring } \\ \text { SAFRR } & \text { Network] } \\ \text { SERNAGEOMIN } & \text { Standardized Emergency Management System } \\ \text { USAID } & \text { U.S. Geological Survey Science Applications for Risk Reduction } \\ \text { USFS } & \text { U.S. Agencional de Geología y Minería de Chile [Chilean National Geology } \\ \text { U.S. Geological Survey Volcano Disaster Assistance Program } \\ \text { U.S. Geological Survey }\end{array}$




\title{
United States-Chile Binational Exchange for Volcanic Risk Reduction, 2015-Activities and Benefits
}

\author{
By Thomas C. Pierson,' Margaret T. Mangan,' Luis E. Lara Pulgar, and Álvaro Amigo Ramos ${ }^{2}$
}

\section{Introduction}

In 2015, representatives from the United States and Chile exchanged visits to discuss and share their expertise and experiences dealing with volcano hazards. Communities in both countries are at risk from various volcano hazards. Risks to lives and property posed by these hazards are a function not only of the type and size of future eruptions but also of distances from volcanoes, structural integrity of volcanic edifices, landscape changes imposed by recent past eruptions, exposure of people and resources to harm, and any mitigative measures taken (or not taken) to reduce risk. Thus, effective risk-reduction efforts require the knowledge and consideration of many factors, and firsthand experience with past volcano crises provides a tremendous advantage for this work. However, most scientists monitoring volcanoes and most officials delegated with the responsibility for emergency response and management in volcanic areas have little or no firsthand experience with eruptions or volcano hazards. The reality is that eruptions are infrequent in most regions, and individual volcanoes may have dormant periods lasting hundreds to thousands of years. Knowledge may be lacking about how to best plan for and manage future volcanic crises, and much can be learned from the sharing of insights and experiences among counterpart specialists who have had direct, recent, or different experiences in dealing with restless volcanoes and threatened populations. The sharing of information and best practices can help all volcano scientists and officials to better prepare for future eruptions or noneruptive volcano hazards, such as large volcanic mudflows (lahars), which could affect their communities.

To this end, the U.S. Geological Survey's (USGS) Volcano Disaster Assistance Program (VDAP) inaugurated a program of reciprocal exchange visits between the United States and other countries faced with potential hazards from active volcanoes - the Binational Exchange for Volcanic Risk Reduction. The program is funded by the U.S. Agency for
International Development's Office of Foreign Disaster Assistance (USAID-OFDA) and by the USGS. These exchanges bring together scientists, civil authorities, first responders, and emergency managers from various countries to discuss and share insights and experiences about the challenges of achieving effective hazard education, response planning, hazard mitigation, and risk reduction.

The first binational exchange in 2013 focused on issues at Mount Rainier (Washington, U.S.A.) and Nevado del Ruiz (Tolima and Caldas Provinces, Colombia) (Beason and others, 2014; Driedger and Ewert, 2015; Westby, 2015). Both of these volcanoes are highly susceptible to lahars. The United StatesColombia exchange allowed participants to share insights on topics ranging from lahar warning systems, self-evacuation planning, and effective education programs for at-risk communities.

The 2015 exchange focused on Chaitén Volcano (Los Lagos region, southern Chile) and the Long Valley volcanic region (California, U.S.A.) (fig. 1), which are both capable of erupting highly explosive rhyolitic magma. During reciprocal exchange visits of about a week each, delegates to the 2015 exchange traveled to both regions to discuss volcano hazards, volcano monitoring, disaster preparedness, and communications with at-risk communities. The Chileans hosted the first leg of the exchange during March 23-30, 2015. Meetings took place in Santiago, Temuco, Pucón, Puerto Varas, Puerto Montt, and Chaitén, with field trips to affected areas near Villarrica and Chaitén Volcanoes to inspect the impacts from recent eruptions and to discuss both official and unofficial responses to these eruptions. The eruption at Villarrica Volcano started on March 3, 2015, and was still ongoing at the time of our visit. The second leg of the exchange occurred in the United States during August 24-30, 2015. Initial meetings took place in Pasadena, California, but most of the meetings and field trips took place in and around Mammoth Lakes, California, in order to review Long Valley volcano-monitoring networks and to discuss response planning and the local impacts of recurring periods of intense volcanic unrest.

${ }^{1}$ U.S. Geological Survey.

${ }^{2}$ Red Nacional de Vigilancia Volcánica del Servicio Nacional de Geología y Minería de Chile. 
The explosivity and rarity of rhyolitic eruptions create unique challenges to risk reduction efforts. For example, the eruption of Chaitén Volcano in 2008 was unexpected - the volcano had been dormant for about 400 years, and little was known of its eruptive history. As a result, the volcano was not seen as a particular threat, and monitoring instrumentation and response protocols were nonexistent. Although eruptioninduced flooding devastated the community, no lives were lost, owing to the impromptu, yet decisive, actions by government and local leaders. The situation in the Long Valley volcanic region is at the other end of the preparedness/response spectrum - its eruptive history is well known, and because of sporadic periods of intense volcanic unrest over the past three decades, sophisticated monitoring networks are in place to detect eruption precursors. Because Long Valley is an area without firsthand experience with eruptions or eruption-related hazards, the challenge for officials and the population there is thus one of maintaining readiness in the face of unrest that continues for decades without any eruption.
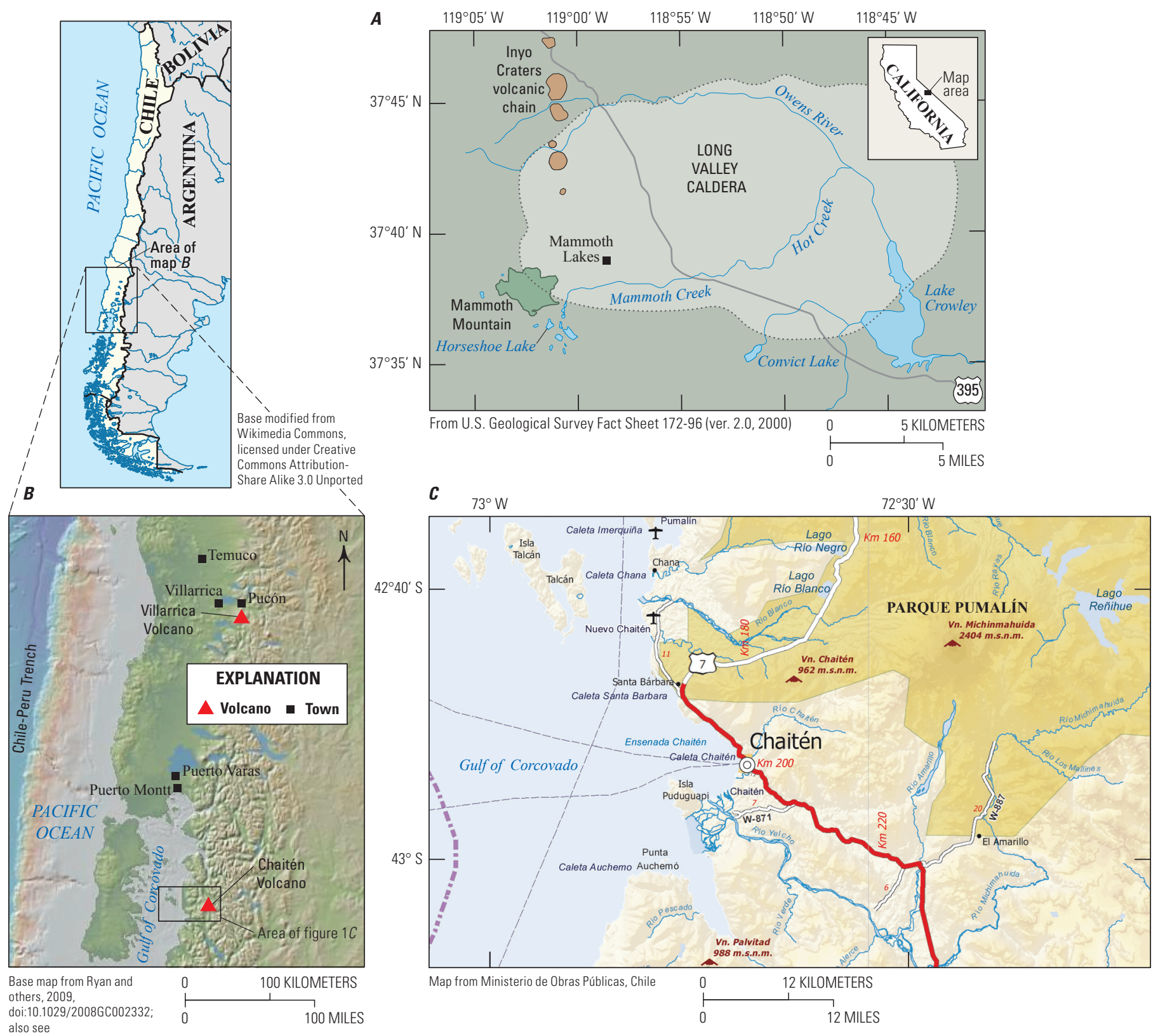

http://www.geomapapp.org

Figure 1. Maps showing locations of $(A)$ the Long Valley volcanic region in California, U.S.A. (modified from Sorey and others, 1996), and $(B$ and $C$ ) Chaitén Volcano region in Chile. In 2015, representatives from the United States and Chile exchanged visits to these regions to discuss and share their expertise and experiences dealing with volcano hazards. Communities in both countries are at risk from various volcano hazards. 


\section{Past Volcanic Activity and Crisis- Response Challenges at Chaitén Volcano and Long Valley Volcanic Region}

\section{Chaitén Volcano}

There was very little warning before the start of the 2008 eruption of Chaitén Volcano (Major and Lara, 2013; fig. 2). With no seismic stations near the volcano, earthquakes directly felt by residents of the town of Chaitén ( 6 miles/10 kilometers, $\mathrm{km}$, downstream of the volcano) provided the first warning of the impending eruption, which commenced about 24 hours later. Following initial steam explosions on May 1, a violent explosive burst on May 2 jetted ash to an altitude of about 65,000 feet (ft) $(20,000$ meters, $m)$ and disrupted air traffic across South America. From May 2 to 8, the volcano continued to erupt violently. About 5,000 residents at risk in the town could not evacuate by road because of heavy ashfall, so evacuation by sea was rapidly organized and largely completed within 24 hours; the last people were out by May 6 . Heavy rains beginning on May 11 washed a tremendous volume of volcanic debris (mostly ash) into the Chaitén River. Volcanic sediment filled the existing river channel, so the river cut a new channel through the middle of the town, depositing as much as $10 \mathrm{ft}(3 \mathrm{~m})$ of mud and sand and partially burying buildings and infrastructure. On two occasions in late 2008 and early 2009, collapses from the volcano's growing lava dome sent searing avalanches of hot gas, ash, and rock (pyroclastic density currents) down the Chaitén River valley to within 2 miles ( $3 \mathrm{~km}$ ) of the town, which by February 2009 had been unofficially reoccupied by hundreds of people.

Flooding and burial destroyed about 80 percent of the town of Chaitén (fig. 3). With the prospect of a lengthy period of dome growth and ongoing hazardous conditions related to potential dome collapse, the Chilean government declared the town unsuitable for habitation in late May 2008. Basic services were shut off, property buyouts were offered, and
Figure 2. An explosive eruptive pulse from Chaitén Volcano, Chile, viewed from town of Chaitén during the first week of its eruption in May 2008. (Photograph courtesy of Servicio Nacional de Geología y Minería de Chile.) 
former residents were encouraged to rebuild homes and businesses in the small settlement of Santa Bárbara-rebranded as "Nuevo Chaitén," about 6 miles $(10 \mathrm{~km})$ to the north. However, the original site of the town of Chaitén offered a deep-water harbor and provided a strong emotional sense of home for the residents, whereas Santa Bárbara had neither. In late 2008, as volcanic activity diminished, hundreds residents began to reoccupy and rebuild the town of Chaitén using portable electric generators and an improvised waterdelivery system to carry on with daily life. In 2012, in the face of growing political pressure, a newly elected national government reversed the exclusion order, partially restored services, and permitted resettlement in the northern part of the town, despite a continuing but lessening threat from the volcano. The partially destroyed southern part of the town is at present illegally occupied by former residents without basic services but with the partial support of the local municipality. To safeguard the community from future hazards, Chaitén Volcano is currently well monitored, thanks to a new, wellfunded volcano-monitoring program in Chile-Red Nacional de Vigilancia Volcánica (RNVV), which is a department of the Servicio Nacional de Geología y Minería de Chile (SERNAGEOMIN) - the establishment of which was prompted by the 2008 eruption of Chaitén Volcano.

Figure 3. Photograph taken June 6, 2008, showing damage to the town of Chaitén, Chile, caused by excessive sedimentation and flooding from the Chaitén River. Sand and gravel deposition here resulted from massive volumes of volcanic ash washing off hillslopes farther upstream during the first rainstorm to follow the main explosive phase of the 2008 eruption of Chaitén Volcano. Sediment filled the channel, forcing the river to flow out of its banks and through the town. (Photograph courtesy of Servicio Nacional de Geología y Minería de Chile.)

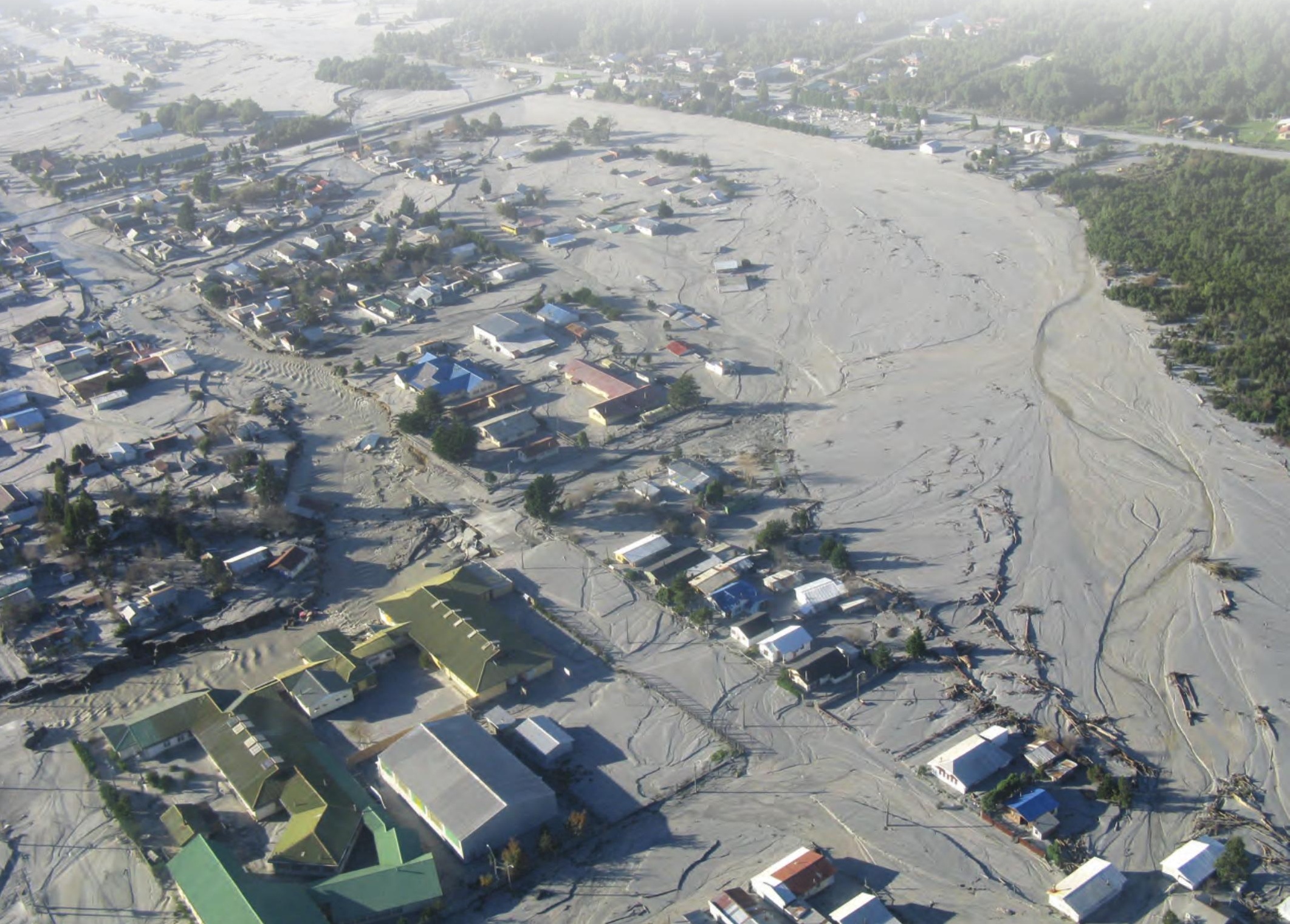




\section{Long Valley Volcanic Region}

Hundreds of mostly explosive rhyolitic eruptions over millions of years have shaped California's Long Valley volcanic region along the eastern front of the Sierra Nevada. Long Valley Caldera (fig. 4), a depression 20 miles (32 km) long, 10 miles $(16 \mathrm{~km})$ wide, and as much as 1 mile $(1.6 \mathrm{~km})$ deep was created by one phase of that volcanic activity-a cataclysmic "super eruption" about 760,000 years ago, and the region continues to be volcanically active (Hill and others, 1985; Miller, 1985; Hildreth, 2004; Hildreth and Fierstein, 2016). Eruptions in the past 100,000 years produced Mammoth Mountain just outside the west rim of Long Valley Caldera. The mountain is partly within the town of Mammoth Lakes, which is home to about 8,000 permanent residents. Because of its natural beauty and abundant outdoor recreational opportunities, the town also hosts millions of visitors each year. Northward from Mammoth Mountain, younger rhyolitic eruptions produced a 10-mile-long (16-km-long) chain of lava domes and volcanic craters (Mono-Inyo Craters), the most recent of which erupted only 250 years ago. In recent years, sporadic periods of intense volcanic unrest under Mammoth Mountain and adjacent parts of the Sierra Nevada and the Caldera have caught the attention of scientists, civil authorities, and the public. In the 1980s and 1990s, powerful earthquake swarms, rapid ground deformation, and intense gas emission episodically affected the area. Although the signals of volcanic unrest have become more subdued in recent years, volcanic gas hazards and the threat of eruption remain.

Decades of waxing and waning volcanic unrest present unique communication challenges about the hazards. For example, during the 1980s, missteps in delivering warnings of potential volcanic activity by the USGS outraged local authorities and residents, who were concerned about impacts on real-estate values and tourism. Most notable was the unforeseen circumstance under which a warning was released to the public. Officials of Mammoth Lakes felt "blindsided" when they first learned that a formal Notice of Potential Hazard was about to be printed in a newspaper article before the USGS had had an opportunity to inform civil authorities and the community at large. In the face of strong public opposition, the USGS backed away from issuing the warning. Since then, scientists have worked to regain and maintain the trust of the community, learning how to communicate hazard information so that undue worry is avoided and economic disruption is minimized.

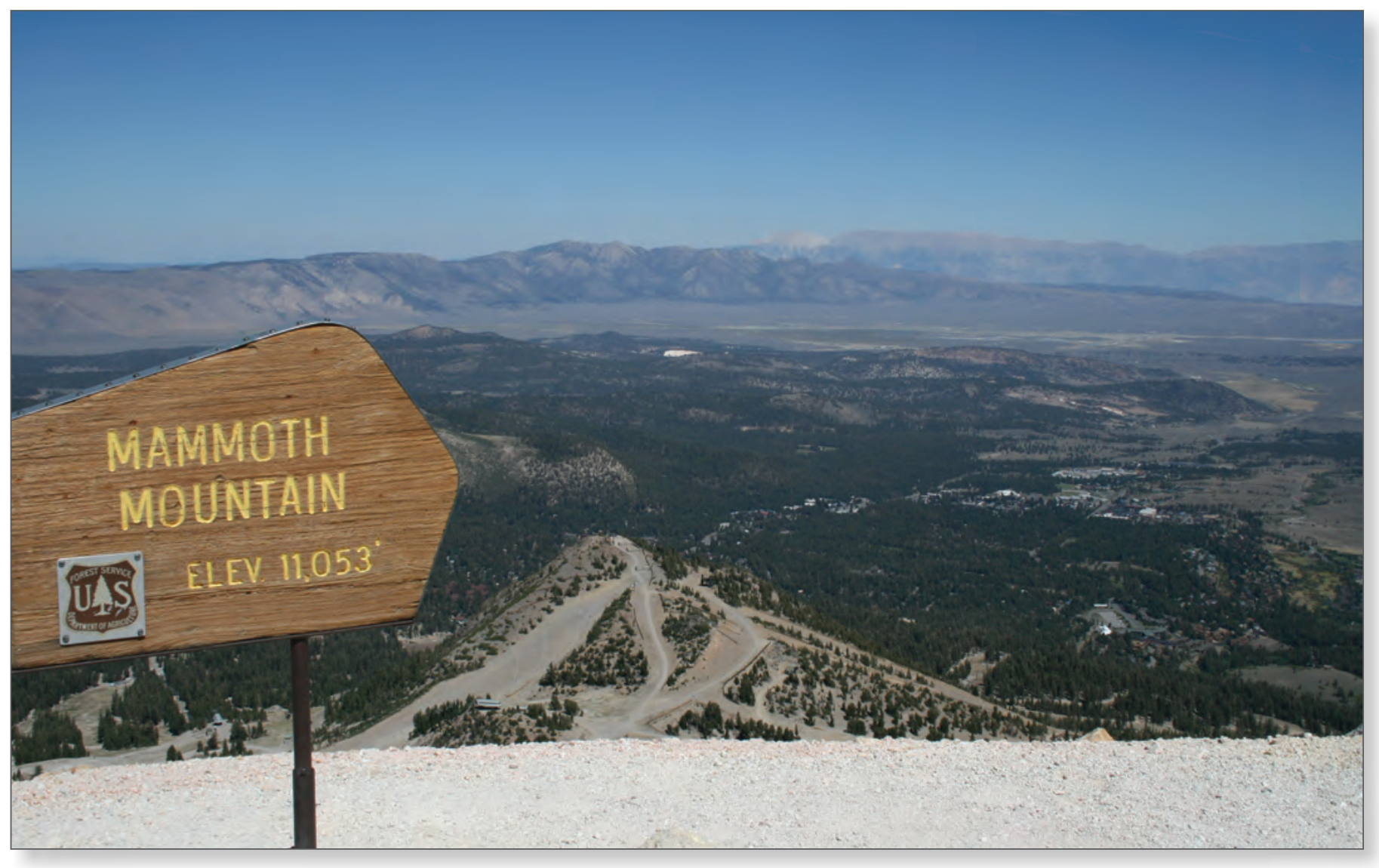

Figure 4. Long Valley Caldera, California, viewed from summit of Mammoth Mountain, a lava-dome complex built on the caldera rim. View northeastward toward the center of the caldera with Mammoth Mountain ski trails immediately below viewpoint, the town of Mammoth Lakes in the near distance on right (forested area), and the east caldera rim formed by the mountain ridge in the far distance. (Photograph by Thomas Pierson, U.S. Geological Survey.) 


\section{Exchange Delegates}

Participants in the binational exchange included 9 delegates from Chile, representing six different agencies or government entities, and 11 delegates from the United States, representing five State and Federal agencies. The delegates and their positions are listed at the front of this report. Wherever possible during the visits, the official exchange delegates were joined by other in-country participants - scientists and local officials involved in various aspects of volcano hazard mitigation. The exchange was coordinated by U.S. delegates Mangan and Pierson and by Chilean delegates Lara Pulgar and Amigo Ramos. Wilkinson, Chavarriga, and Lopez provided most of the translation services during the exchange visits.

\section{Exchange Activities in Chile}

The U.S. delegation arrived in Santiago, Chile, on Sunday, March 22, 2015. Starting on the morning of March 23, the delegation was briefed by high-level officials at the headquarters for three national agencies-SERNAGEOMIN (the Chilean Geology and Mining Service), Oficina Nacional de Emergencia (ONEMI; the national emergency-response agency), and the National Seismological Center at the University of Chile (fig. 5). These visits afforded opportunities to learn about the organization and infrastructure of the emergency management of volcanic and earthquake hazards in Chile.
After a late afternoon flight to Temuco on March 24, scheduled activities included a briefing at the Southern Andean Volcano Observatory (OVDAS), SERNAGEOMIN's main observatory (fig. 6), and a day trip to the town of Pucón. In Pucón, delegates (1) examined the site of a lahar that had occurred on the southern flank of Villarrica Volcano on March 3 during the volcano's 2015 eruption (fig. 7), (2) attended a reception luncheon hosted by the municipality of Pucón, and (3) participated in a debriefing meeting between local, regional, and national officials following emergencyresponse activities carried out during the just-concluded eruption crisis (fig. 8). This meeting provided an unexpected opportunity to learn what can happen during a volcanic crisis. Discussions revealed that at the height of the crisis, confusion occurred over posted alert levels and evacuation orders, owing to communication breakdowns between volcano scientists, national-level emergency managers, and the local officials who had needed to make some quick decisions as the level of eruptive activity rapidly increased. In response to the frustrations expressed by several local officials, the national- and regional-level officials who were part of the exchange delegation listened and offered explanations, allowing for frank discussions of how emergency response during a volcanic crisis might be improved. These discussions gave the U.S. delegates a realistic view of the kinds of issues commonly faced by authorities dealing with volcano crises, including the practical challenges of dealing with rapidly changing forecasts and coordinating an emergency response among various governmental agencies.

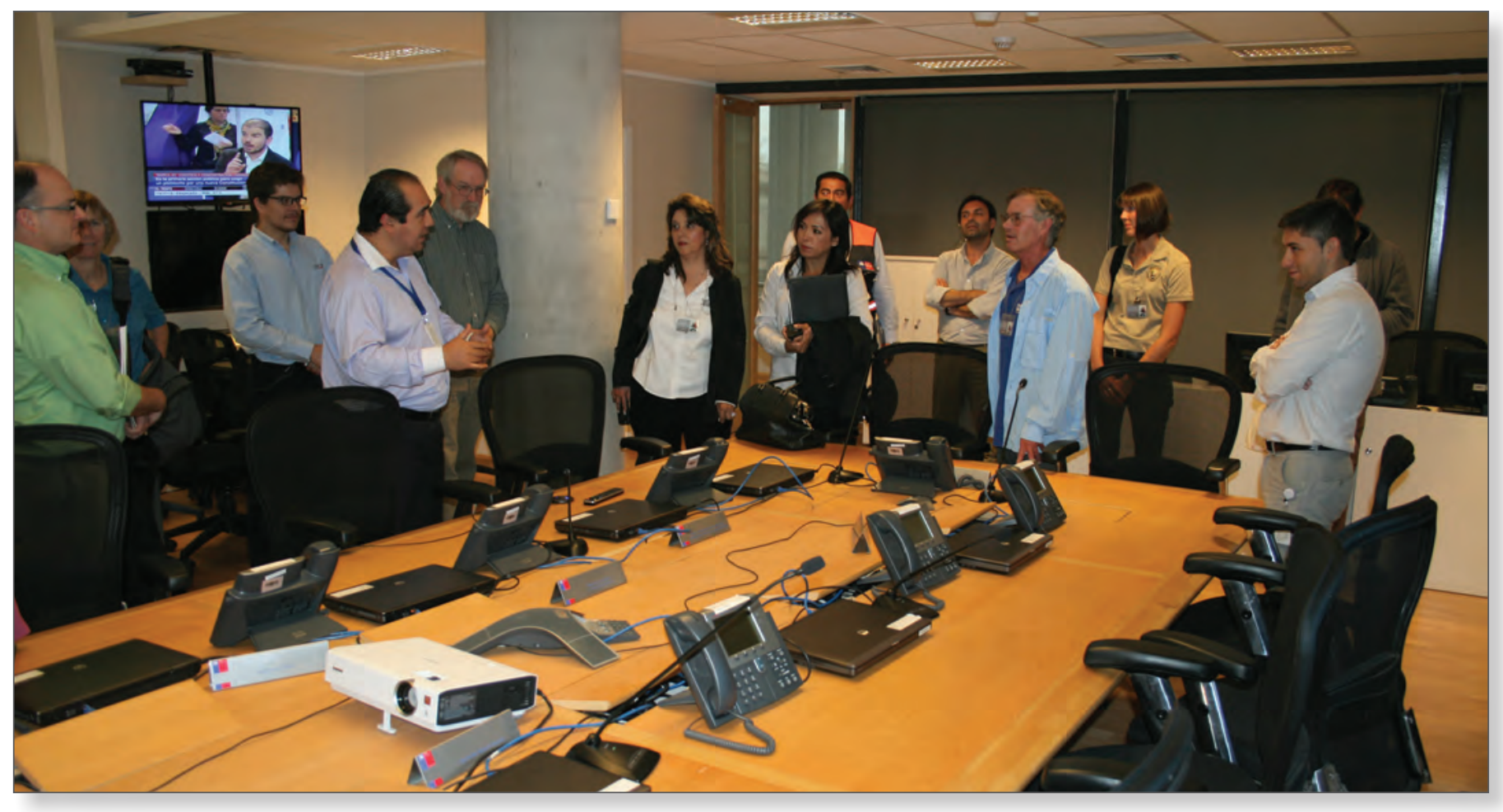

Figure 5. A briefing to U.S. delegates at the National Seismological Center at the University of Chile. (Photograph by Thomas Pierson, U.S. Geological Survey.) 

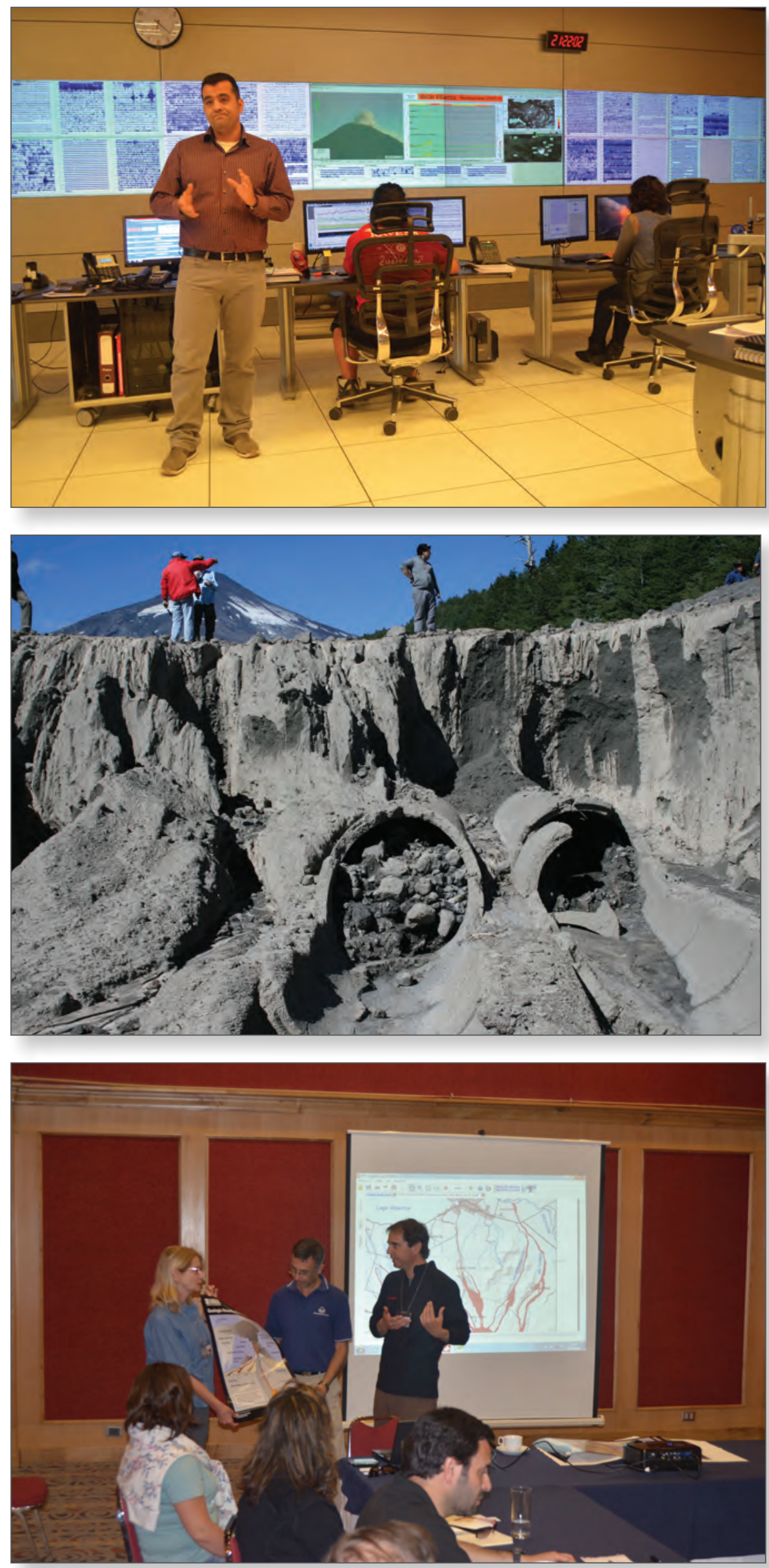

Figure 6. A briefing to U.S.-Chile-exchange participants on volcano monitoring in the southern Andes by the chief of seismic monitoring at Observatorio Volcanológico de Los Andes del Sur (OVDAS). Active volcanoes in southern Chile are monitored from this observatory, primarily using seismicity. (Photograph by Christopher Wills, California Geological Survey.)

Figure 7. U.S.-Chile-exchange participants examining deposits and damage caused by a lahar on March 3 during the 2015 eruption of Villarrica Volcano, Chile (in background). (Photograph by Thomas Pierson, U.S. Geological Survey.)

Figure 8. Presentation of U.S. Geological Survey volcano hazard posters to the Mayor of Pucón, Chile, by a U.S.-Chile exchange coordinator during the first meeting of officials after evacuation of the town during the March 2015 eruption of Villarrica Volcano. (Photograph by Christopher Wills, California Geological Survey.) 
On March 26, the entire group traveled to Puerto Varas and met that afternoon with ONEMI staff at the Los Lagos regional office of ONEMI in nearby Puerto Montt. Delegates were briefed further on the organizational structure and responsibilities of ONEMI during volcanic eruptions and on the emergency plan for this jurisdictional region of the country. The delegation also received updates on an ongoing nearby wildfire by an official from Corporación Nacional Forestal (CONAF), the national forestry corporation.

During March 27-29, the delegates visited the area around Chaitén Volcano. Pedro Vásquez Celedón, mayor of Chaitén, and Karem Cofré Orellana, Chief of Palena Province Social Services briefed the other delegates on the evacuation of the town of Chaitén and the somewhat-complex history of the town's recovery after the heavy damage caused by the 2008 eruption-induced lahar and flood. Later, delegates heard about eruption impacts to infrastructure and the rural population by Carlos Zambrano, general manager of Pumalín Park, a large, foundation-administered, private nature reserve surrounding Chaitén Volcano. All three of these officials were part of the Chilean delegation. Delegates also learned about the experiences of some of the local residents during the eruption from the proprietor of our hotel in Chaitén. The rest of the time in the town included walking tours to see damage caused by flooding and sediment deposition, and then a hike to the volcano's caldera rim (fig. 9 and cover photograph). March 30 began two days of travel back to the United States.

Figure 9. Juxtaposition of a recently built and currently occupied municipal building (on left) with the ruins of a partially buried (in 2008) and now decaying and unoccupied house (right) in the town of Chaitén, Chile. (Photograph by Thomas Pierson, U.S. Geological Survey.)

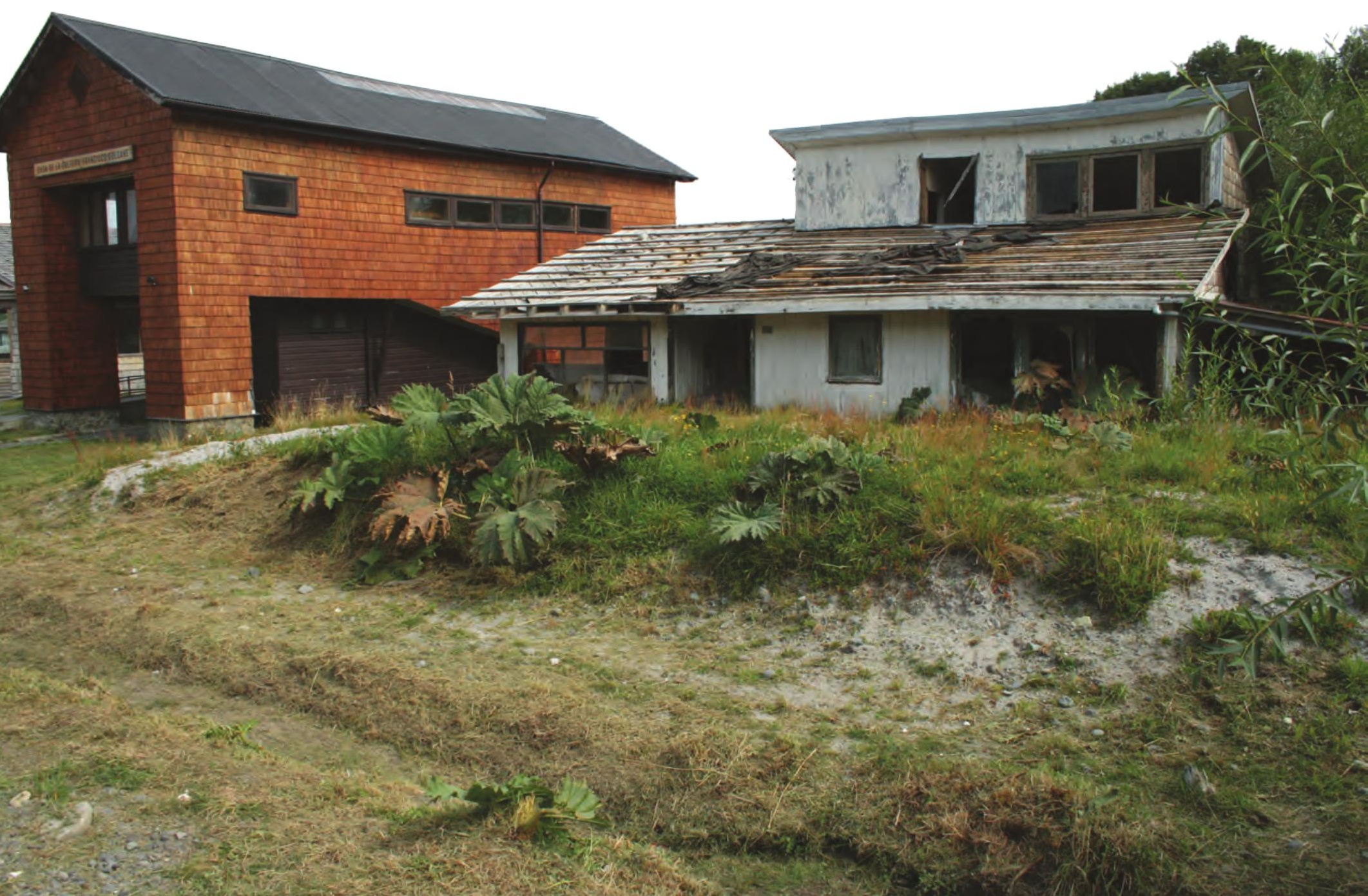




\section{Exchange Activities in the United States}

The second half of the binational exchange began with the arrival of the Chilean delegation in Los Angeles, California, on August 23. The group then drove to the home of Mona Bontty (U.S. delegate) for a welcome luncheon. The California leg of the exchange included the original Chilean and U.S. delegates (listed above), as well as seven representatives from the U.S. Forest Service (USFS), U.S. Geological Survey (USGS), National Park Service (NPS), California Geological Survey (CGS), and California Governor's Office of Emergency Services (Cal OES), who had learned of the exchange and participated in parts of the scheduled program. Additionally, an administrator and a public outreach specialist from the USGS Cascades Volcano Observatory (CVO)_-Sara Jivanjee and Elizabeth Westby, respectively-joined the group to help with logistics and with documentation of the proceedings.

The first phase of the week's activities focused on Federal and State management of natural hazards in California. Activities on August 24 in USGS's Pasadena office included morning briefings on the USGS's Science Applications for Risk Reduction (SAFRR) project by Lucy Jones (then USGS Science Advisor for Risk Reduction) and on the USGS Earthquake Early Warning program by Douglas Given (USGS Earthquake Early Warning coordinator). U.S. delegate Christopher Wills also gave an overview of natural-hazard riskreduction strategies promulgated by CGS. Afternoon briefings included an overview of the USGS Volcano Hazards Program by Thomas Murray, director of the USGS Volcano Science Center, and an introduction to Cal OES by U.S. delegates

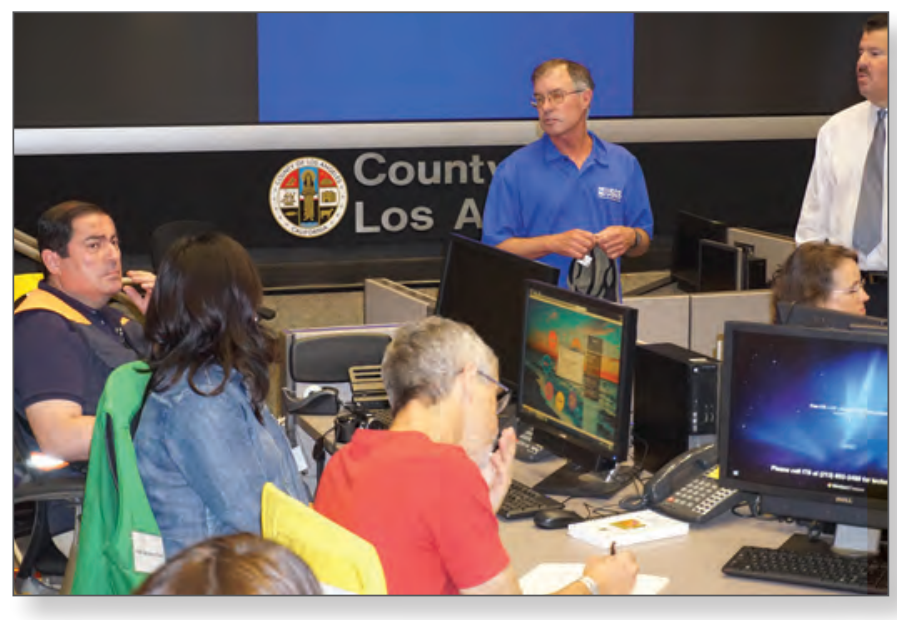

Figure 10. A briefing to U.S.-Chile-exchange participants on operational protocols and responsibilities of emergency managers at the Los Angeles County Emergency Operations Center. (Photograph by Christopher Wills, California Geological Survey.)
Helen Lopez and Mona Bontty. This phase of the exchange concluded the next morning with a briefing by Steven Lieberman, assistant director for operations at the Los Angeles County Emergency Operations Center (EOC) (fig. 10). This overview gave delegates some insight into how emergency responses are handled through a technologically sophisticated EOC in a large, but locally managed, jurisdiction of 12 million people (88 cities, towns, and unincorporated municipalities).

On August 25, the delegates drove from Los Angeles to Mammoth Lakes for the second phase of exchange activities, where focus shifted from emergency management to volcanohazard assessment and risk-reduction strategies in the complex and restless Long Valley volcanic region. The next day, Wednesday, August 26, was devoted to a geologic overview of this high-threat volcanic system that most recently erupted about 250 years ago. In the morning, the group took a gondola ride to the summit of Mammoth Mountain on the rim of Long Valley Caldera for a bird's-eye view of the region from 11,053 feet (3,369 m) (fig. 11). There, Edward (Wes) Hildreth and Judith Fierstein (both with CalVO) provided an overview of regional geology and the eruptive history of Long Valley. In the afternoon, the two scientists led a field trip to the Owens River Gorge, where the group examined a massive pyroclastic flow produced during the catastrophic "super eruption" of Long Valley Caldera about 760,000 years ago. According to Hildreth and Fierstein, future Long Valley eruptions are likely to be less energetic and to occur either near Mammoth Mountain (and the resort town of Mammoth Lakes) or along the Mono-Inyo Craters chain that extends northward from Mammoth Mountain to Mono Lake, where the most recent eruption occurred. The day ended with a reception at the home of long-time Mammoth Lake residents, Robert and Sally Drake.

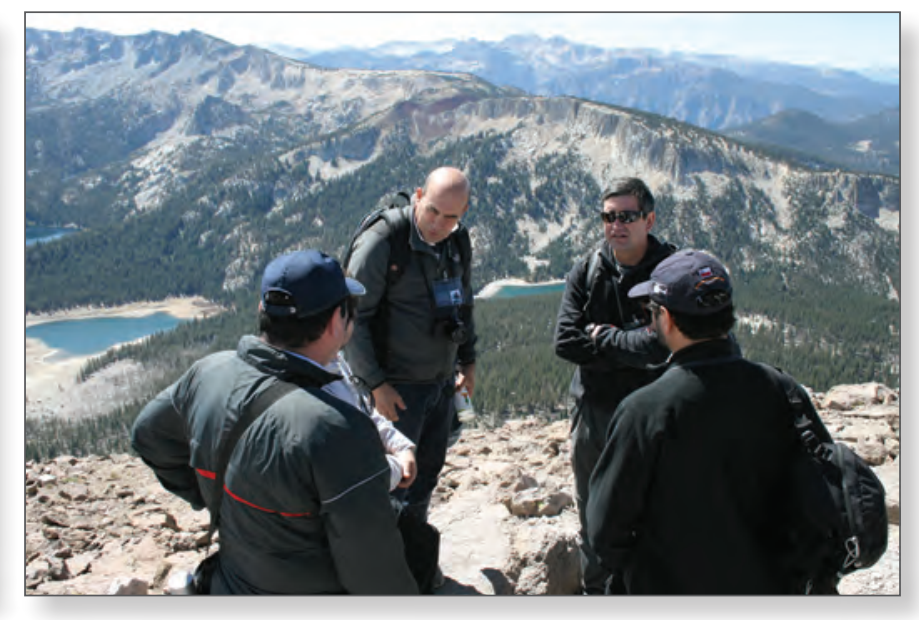

Figure 11. A discussion among Chilean delegates on summit of Mammoth Mountain, California, with a view of Horseshoe Lake (a carbon dioxide $\left[\mathrm{CO}_{2}\right.$ ] gas hazard area) in the background. (Photograph by Thomas Pierson, U.S. Geological Survey.) 
During the reception, David Hill (CalVO) gave an overview of the recent history of volcanic unrest in Long Valley-sporadic earthquakes, ground deformation, and gas emissions spanning more than three decades - and Sally Drake provided insight on the effect of the prolonged unrest on residents and businesses. Also present were John Eastman (former mayor of Mammoth Lakes) and Thomas Heller (Mammoth Lakes fire marshal), who added to the numerous small-group discussions that occurred on the various aspects of how natural hazards are perceived in communities where local residents sometimes fear that highlighting potential hazards can negatively affect tourism and real-estate values.

Activities on the next day (August 27) focused on the Long Valley hydrothermal (volcanically heated groundwater) system. In the morning, the group visited the Ormat Geothermal Power Plant on the outskirts of Mammoth Lakes. After the visit, Jennifer Lewicki (CalVO) described monitoring of volcanic carbon dioxide $\left(\mathrm{CO}_{2}\right)$ gas emissions in Long Valley (fig. 12). The group learned that (1) an increase in $\mathrm{CO}_{2}$ emissions can precede a volcanic eruption and (2) $\mathrm{CO}_{2}$ is a potential hazard in itself - it is a heavier-than-air gas that, although not toxic, can collect in low-lying areas (or under snowpack), where concentrations can build to levels causing suffocation. For example, in 2006 two ski patrollers fell into a $\mathrm{CO}_{2}$-filled snow pit above a fumarole (volcanic steam/gas vent) at the Mammoth Mountain ski area and were asphyxiated, and a third person died trying to rescue them. In the afternoon, the group visited Horseshoe Lake - another area at the base of Mammoth Mountain where $\mathrm{CO}_{2}$ emissions were concentrated enough in 1998 to cause the death of another person who fell into a $\mathrm{CO}_{2}$-filled depression in the snow next to a building. $\mathrm{CO}_{2}$ buildup in the soil has also killed trees over an extensive area at Horseshoe Lake.

On August 28, the focus shifted to volcanic-disaster preparedness, mitigation, and response. Morning briefings at the Mammoth Lakes Fire Department conference room began with an overview given by NPS Rangers (and U.S. delegates) Ronald Martin and Kristin Kirschner (fig. 13) of the Incident Command System (ICS) and the National Incident Management System (NIMS). These are highly effective command and control systems that have been widely adopted for emergency management during crises in the United States. This first presentation was followed by examples of tabletop scenario exercises, also explained by Rangers Martin and Kirschner. Finally, the Mammoth Lakes Police Department explained how a Community Emergency Response Team (CERT) operates and showed equipment that is used by the local team. The afternoon session started with an introduction by U.S. delegate Nathan Wood (USGS) about how vulnerable communities can lessen their risk from volcano hazards. This was followed by an overview from Thomas Pierson (USGS; U.S. co-coordinator of the exchange) of the Federal

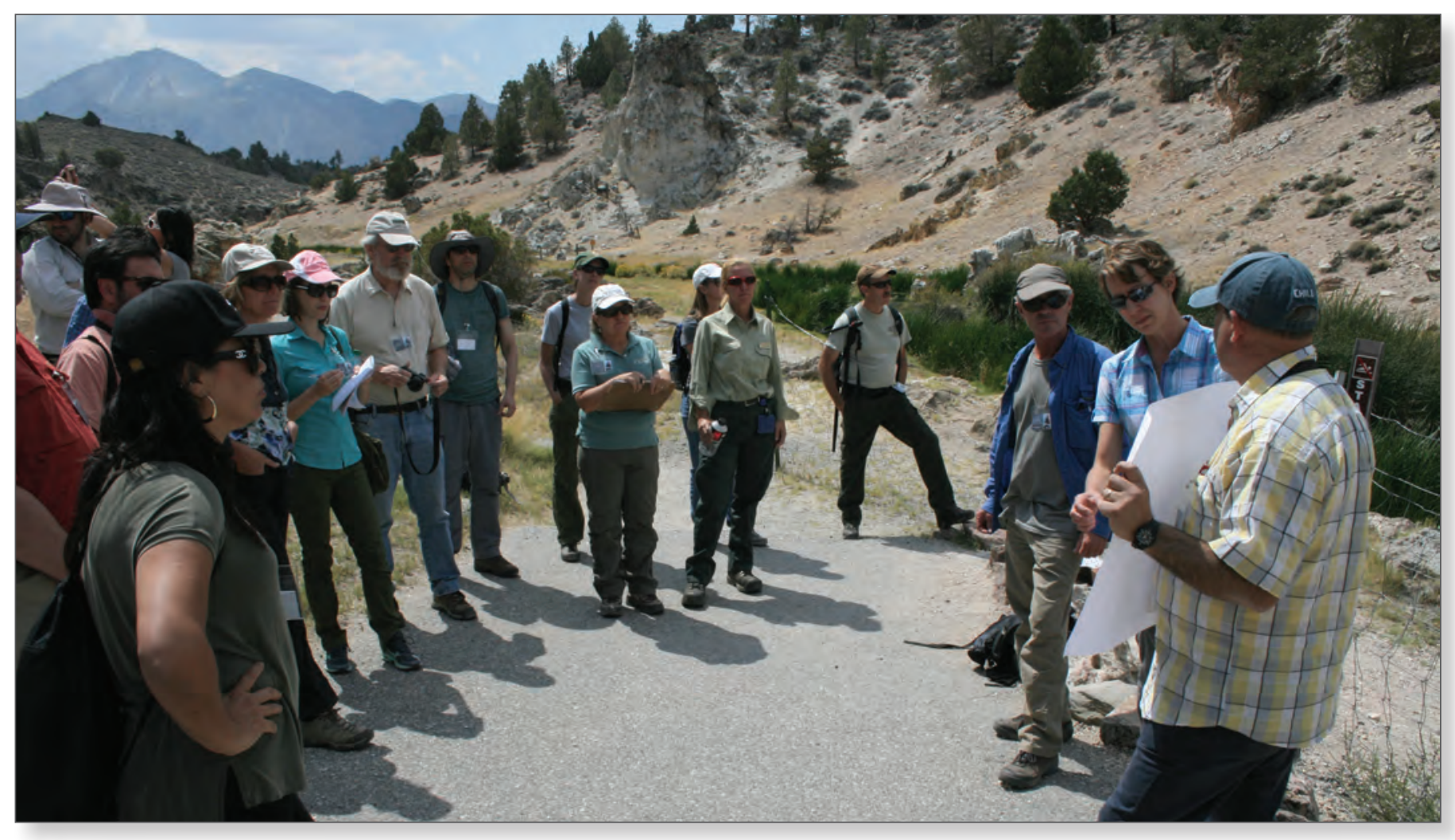

Figure 12. U.S. Geological Survey (USGS) geologist explaining to U.S.-Chile-exchange participants USGS efforts to monitor and understand carbon dioxide $\left(\mathrm{CO}_{2}\right)$ gas release in the Long Valley Caldera, California. The group is at Hot Creek, the site of numerous hot springs and fumaroles. (Photograph by Thomas Pierson, U.S. Geological Survey.) 
Emergency Management Agency's (FEMA) Volcanic Crisis Awareness Course - a newly developed tool for educating emergency managers about volcano hazards. The day's activities concluded with a visit to Devils Postpile National Monument and a discussion of the challenges of emergency evacuation during a crisis from locations with numerous visitors and only limited or restricted escape routes. Deanna Dulen (monument superintendent) hosted this visit.

The final day of the exchange, August 29, began with a visit to Yosemite National Park to learn about NPS

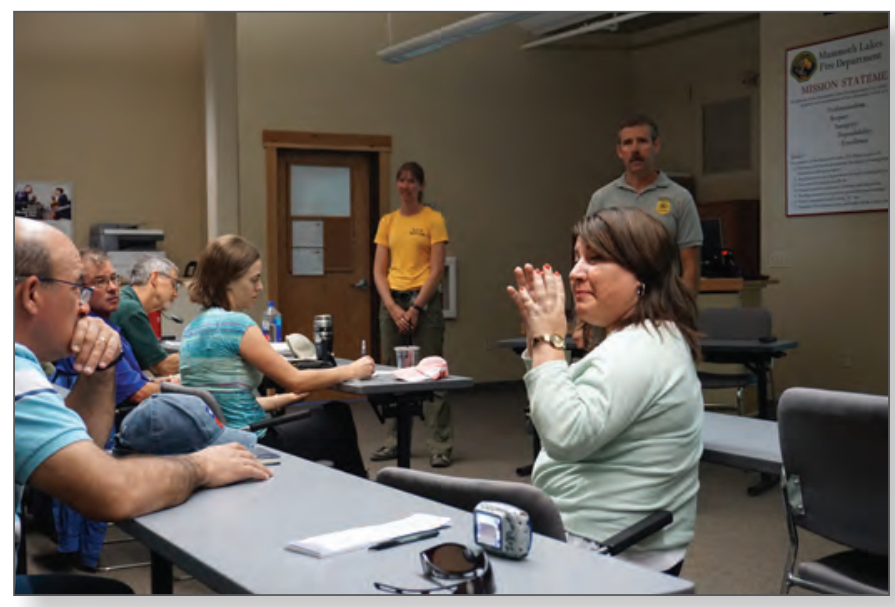

Figure 13. A U.S.-Chile exchange group discussion during overview of the Incident Command System, the National Incident Management System, and tabletop scenario exercises being presented by National Park Service rangers. (Photograph by Christopher Wills, California Geological Survey.) emergency-management and emergency-response philosophy, training, and preparation, as well as to take in the incredible Sierra Nevada scenery (fig. 14). NPS Ranger Kristin Kirschner (U.S. delegate) led this visit. On the way back to Mammoth Lakes, the group stopped at Mono Lake - a hypersaline lake that anchors the north end of the Mono-Inyo Craters chain. Stuart Wilkinson (U.S. delegate) explained the unique ecology of the lake. Finally, from the shores of Mono Lake, geologist Judith Fierstein (CalVO) (fig. 15) explained the recent eruptive history of the Mono-Inyo Craters.

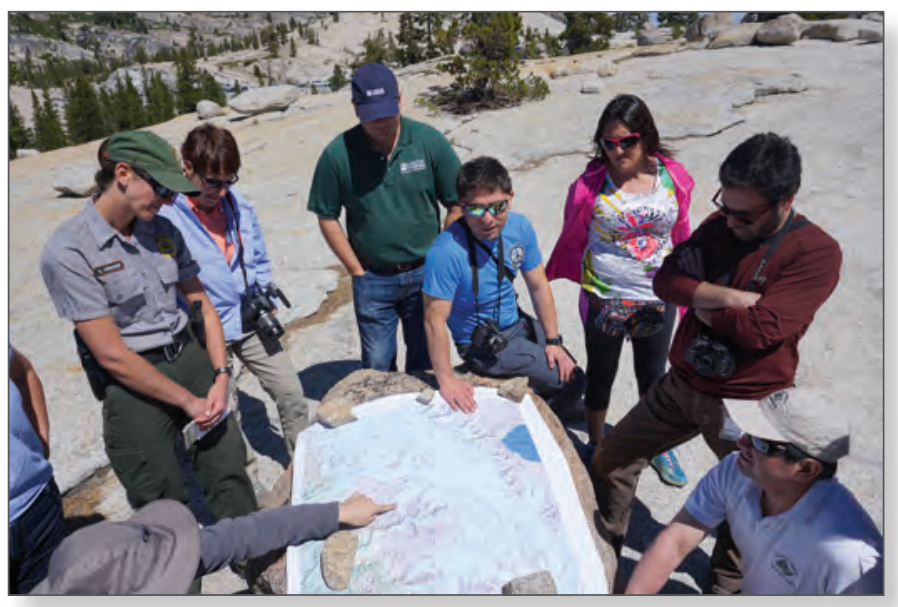

Figure 14. U.S.-Chile-exchange participants receiving an explanation of Yosemite National Park, California, access roads and visitor flow in order to understand National Park Service emergency-management and emergency-response philosophy, training protocols, and preparations for emergencies. (Photograph by Thomas Pierson, U.S. Geological Survey.)

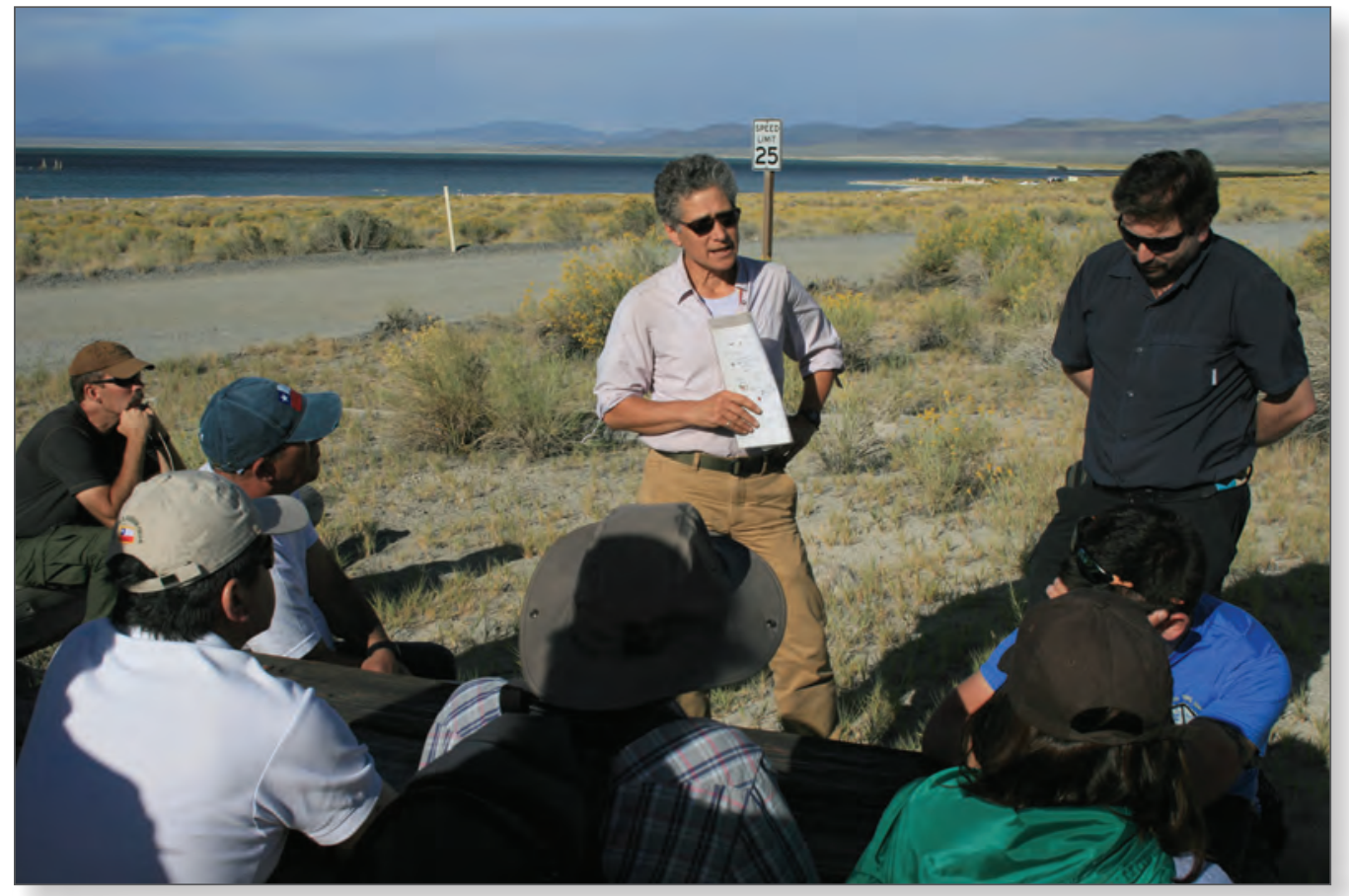

Figure 15. U.S.-Chileexchange participants, gathered on the shore of Mono Lake, California, receiving an explanation by a U.S. Geological Survey geologist of the eruptive history and hazards of the Mono-Inyo Craters. (Photograph by Christopher Wills, California Geological Survey.) 


\section{Benefits for Exchange Participants}

To assess the levels of knowledge and areas of interest of delegates with regard to volcano hazards, both U.S. and Chilean delegates filled out pretrip and posttrip questionnaires. The pretrip questionnaire targeted delegates' knowledge about volcano hazards and emergency-management-protocols in their respective countries. They also assessed what each delegate personally hoped to gain from the exchange. The posttrip questionnaire assessed the delegates' new insights and understandings gained after participation in the exchange. Responses were thoughtful and detailed, and individual answers (with names deleted and answers in Spanish translated into English) appear in appendixes 1 and 2).

\section{Pretrip Questionnaire Responses}

Learning objectives brought by the U.S. and Chilean delegates to the exchange were broadly similar but with some differences in emphasis. Articulation of objectives beforehand seemed to help form the basis for many presentations and fruitful discussions during the exchange.

\section{Summary of U.S. Delegate Perspectives}

On the basis of nine pretrip questionnaire responses, U.S. delegates set personal goals that they hoped to achieve and formulated questions they hoped to have answered. Learning objectives focused mainly on specific decisions or actions that might be required of them during a volcanic crisis. Many delegates had questions about (1) when to issue alerts and evacuation orders; (2) how to predict the long-term impacts of eruptions; (3) how volcanic crises differ from other emergencies, such as wildfire, with which many were familiar; (4) what issues are important in recovery and resettlement; and (5) what best practices have been distilled from emergencyresponse experiences in Chile. Most of the U.S. delegates were familiar with the emergency-response plans for their own jurisdictions, although most of these were all-hazards plans (not focused on volcano hazards) that involved a multiagency response and establishment of an ICS for major crises. Specific questions common among the U.S. delegates included:

- What are some best practices for conducting evacuations during a crisis?

- How are decisions made to evacuate towns in Chile, and how is community exposure assessed?

- How are protocols established for incident notification, issuing alerts, and evacuating populations?

- How are indigenous populations treated with regard to education and information dissemination (for example, are language, cultural issues, and remote communities addressed)?
- What are some of the long-term impacts of eruptions that affect the recovery of communities?

- How can first responders best be protected during a volcanic crisis?

\section{Summary of Chilean Delegate Perspectives}

For the Chilean delegates (based on seven responses), goals for the exchange before their visit to California in August 2015 could be largely divided between desires to gain a broad overview understanding of how volcanic crises are handled in the United States and to learn specific approaches or methodologies that might help solve problems or overcome challenges encountered in Chile. The Chilean delegates also had set several personal goals and formulated questions that involved the roles and responsibilities of their particular agencies and challenges faced while working to fulfill their duties. In general, the Chilean delegates had a strong sense of what the responsibilities were for their respective agencies, but it was unclear from the questionnaires whether comprehensive (and well-practiced) emergency-response protocols were in place at either the national or regional levels - an interagency command system like ICS for the management of emergencies is not widely used in Chile. The hoped-for new perspectives for the Chilean delegates were extensive and focused on several general areas but also on many specific questions:

- How can communities best prepare for volcanic crises?

- How are risk maps made and used in the United States?

- How is scientific information integrated into response plans before a crisis, and then how is it shared with emergency managers during a crisis?

- What computer applications or tools can be used to help manage risk?

- How are volcano observatories in the United States set up and organized?

- What kinds of studies are carried out at U.S. volcanoes to better understand the hazards?

- How do emergency managers communicate warnings to the public, particularly in large parks with dispersed visitor populations?

- How are the media used during crises?

- How are at-risk communities educated about hazards in the United States?

- What is a formula for a good emergency-response plan?

- How are emergency-response plans integrated among various agencies?

- How are warning alert systems set up and operated in the United States? 
- What methods are used to foster/implement better communication among emergency managers and scientists?

- How are issues of overlapping responsibility and jurisdiction ("turf issues") among different agencies handled during crises?

- How much scientific information should scientists give out to managers, officials, and the public during crises (in other words, how much is too much)?

- How should exclusion zones be managed during a crisis?

- What criteria are used to decide when to change volcano alert levels?

\section{Posttrip Questionnaire Responses}

\section{U.S. Delegate Perspectives}

Answers based on nine responses strongly suggest that all of the U.S. delegates gained a greater understanding of the issues and challenges inherent in managing volcano hazards. These insights came not only from their visit to Chile but also from a more in-depth examination of Long Valley hazards and emergency-response challenges. Interactions with their Chilean counterparts, presentations by technical experts, and observations on how the recent crises at Villarrica and Chaitén Volcanoes were perceived and responded to all broadened their perspectives. Many key insights were shared among U.S. delegates, although many other new perspectives (see appendix 2) were specific to the communities, systems, and agencies of which the delegates are part of in the Long Valley region. New insights held in common include:

- Response planning depends on the overall system of government - highly centralized, hierarchical systems tend to produce top-down plans; less centralized systems with more distributed responsibilities at local levels tend to produce bottom-up plans. Organizational structure is important.

- Good communication about hazards among scientists, emergency managers, and the public is difficult before, during, and after a crisis; good communication requires hard work.

- People in at-risk communities need a good understanding of potential hazards and necessary responses during a crisis.

- At-risk communities need more and better education about volcano hazards.

- High turnover rates of emergency-management officials and public complacency are two major obstacles to hazard preparedness.

- Politics play an important role in resettlement and recovery after disasters.
- Although an all-hazards approach to natural disasters is the dominant and appropriate approach to response planning, but it might be good to do more to educate key players on California ICS teams about the unique aspects of volcanic crises in comparison to other hazards.

- People and institutional resources in affected communities definitely need to be part of the response-planning process.

- Volcanic crises can have much longer durations than the emergencies to which many crisis managers must respond.

\section{Chilean Delegate Perspectives}

After the visit to California, answers by the Chilean delegates to the posttrip questionnaire revealed that they came away with many new insights and ideas. Five of the nine Chilean delegates responded; some of the more general comments include:

- Scientists need to participate in educating communities about hazards.

- Effective hazard mitigation depends on government policies that promote integration of the scientific data with emergency management.

- Emergency-management systems can be effectively run in a decentralized fashion involving the bottom-up participation of people in local communities; the topdown model originating from our national government is not the only model.

- Coordination of emergency-response plans among agencies, institutions, and communities in advance of a crisis is crucial for effective crisis management.

- Journalists and the media play key roles in the communication of information during emergencies.

- Compartmentalization of agencies and institutions can lead to detrimental attitudes and consequences during emergencies, such as a reluctance and failure to share data and information.

- The responsibility for education of at-risk communities about hazards needs to be built into the protocols and cultures of agencies and institutions; it should not be left to the initiative of individual scientists or emergency managers.

- It is important to have an institutionalized process of assigning work responsibilities and resources (within a specified legal framework) that allows multiple agencies to work under a single standard during an emergency response. Within the United States, this process is ICS. 


\section{Summary}

The 2015 United States-Chile Binational Exchange for Volcanic Risk Reduction, sponsored by the USGS and USAID-OFDA, involved scientists, emergency managers, and public officials from the United States and Chile in reciprocal visits of about a week in duration to active volcanic regions in each other's countries. The visit to southern Chile took place March 23-30, and the California visit occurred August 24-30, 2015. The shared encounters with real volcano-monitoring and hazard-mitigation issues enabled the delegates to learn from local experts and from each other about how vulnerable populations can be better prepared to deal with volcanic eruptions, how best practices for emergency response are continuously being modified by direct experience, and how volcanic risk ultimately can be reduced.

Although the Chile leg of the exchange focused initially on Chaitén Volcano in northern Patagonia, an eruption of Villarrica Volcano that involved community evacuations started only weeks before the visit by the U.S. delegation, allowing the scope of the visit to be broadened. The U.S. leg of the exchange focused on emergency operation systems in the Los Angeles area and on hazards monitoring and crisis-response planning in the Long Valley volcanic region in the eastern Sierra Nevada. Chaitén Volcano and Long Valley were chosen for this exchange because both are centers of rhyolitic volcanism. The high viscosity and gas content of rhyolitic magma can cause explosive eruptions with widespread destruction. Rare but catastrophic "super eruptions" have largely been the result of rhyolite volcanism.

Exchange activities included site visits to areas of volcanic unrest and eruption, presentations by subject-matter experts, and facility tours - all of which provided opportunities for informal social interaction and exchange of ideas. Delegates examined and compared types and threats of volcano hazards, volcano-monitoring strategies, approaches to disasterpreparedness planning, and methods of communications with at-risk communities. Both U.S. and Chilean delegates reported gaining new insights and understanding from the exchange, as well as increased motivation to improve the status quo for volcanic-risk management in their home jurisdictions.

\section{References Cited}

Beason, S., Driedger, C., Lockhart, A., Schelling, J., Gibson, Z., Burkhart, F., Banks, D., Bustad, K., Allen, R., and Scott, M., 2014, Lessons learned from a bi-national exchange between Colombia and the United States-Real-life emergency planning and preparedness from a worst-case scenario: Geological Society of America Annual Meeting, Vancouver, British Columbia, October 19-22, 2014, accessed March 14, 2017, at https://gsa.confex.com/gsa/2014AM/ webprogram/Paper244620.html.
Driedger, C., and Ewert, J., 2015, Volcano-hazards education for emergency officials through study trip learning-The 2013 binational exchange: American Geophysical Union Fall Meeting, San Francisco, Calif., December 14-18, 2015, abstract 76171, accessed March 14, 2017, at https://agu. confex.com/agu/fm15/meetingapp.cgi/Paper/76171.

Hildreth, Wes, 2004, Volcanological perspectives on Long Valley, Mammoth Mountain, and Mono Craters-Several contiguous but discrete systems: Journal of Volcanology and Geothermal Research, v. 136, p. 169-198, doi: 10.1016/ j.jvolgeores.2004.05.019.

Hildreth, Wes, and Fierstein, Judy, 2016, Eruptive history of Mammoth Mountain and its mafic periphery, California: U.S. Geological Survey Professional Paper 1812, 128 p., 2 plates, scale 1:24,000, accessed March 14, 2017, at https://doi.org/10.3133/pp1812.

Hill, D.P., Bailey, R.A., and Ryall, A.S., 1985, Active tectonic and magmatic processes beneath Long Valley Caldera, eastern California-An overview: Journal of Geophysical Research, v. 90, no. B13, p. 11111-11120, accessed March 14, 2017, at http://dx.doi.org/10.1029/ JB090iB13p11111.

Major, J.J., and Lara, L.E., 2013, Overview of Chaitén Volcano, Chile, and its 2008-2009 eruption: Andean Geology, v. 40, p. 196-215.

Miller, C.D., 1985, Holocene eruptions at the Inyo volcanic chain, California-Implications for possible eruptions in Long Valley Caldera: Geology, v. 13, p. 14-17.

Pierson, T.C., Major, J.J., Amigo, Á., and Moreno, H., 2013, Acute sedimentation response to rainfall following the explosive phase of the 2008-2009 eruption of Chaitén volcano, Chile: Bulletin of Volcanology, v. 75, article no. 723, accessed March 14, 2017, at http://dx.doi.org/10.1007/ s00445-013-0723-4.

Sorey, M.L., Farrar, C.D., Gerlach, T.M., McGee, K.A., Evans, W.C., Colvard, E.M., Hill, D.P., Bailey, R.A., Rogie, J.D., Hendley, J.W., II, and Stauffer, P.H., 1996, Invisible $\mathrm{CO}_{2}$ gas killing trees at Mammoth Mountain, California (ver. 2.0, June 2000): U.S. Geological Survey Fact Sheet 172-96, accessed April, 26, 2017, at https://pubs.usgs.gov/ fs/fs172-96/.

Westby, L., 2015, Colombia-USA Binational Exchange: U.S. Geological Survey video, accessed March 14, 2017, at https://www.youtube.com/watch?v=MNp_7iVtd28 (Spanish version, https://www.youtube.com/ watch? $\mathrm{v}=\mathrm{Xb} 7 \mathrm{GSZ9X} \mathrm{smI})$. 
Appendixes 


\section{Appendix 1. Pretrip Questionnaires}

\section{U.S. Delegate Responses to Chile Pretrip Questionnaire}

\section{U.S. Delegate Response 1}

1. What specific insights do you hope to gain from this trip?

- I'd like to gain some insight into the impact of the Chaitén eruption on fluvial systems and how that might apply to Crowley Lake and other key pieces of infrastructure in California.

- I'd like to learn more about how long-term planning can apply in areas subject to volcano hazards. We have a lot of experience with other hazards in statewide mitigation plans, hazard zones, and emergencyresponse plans, so I'd like to learn more about how some of the techniques we use for other hazards can apply to volcano hazards.

2. List three questions that YOU want to see answered concerning effective volcano response.

- Can the planning scenario concept used for earthquakes in California be adapted for volcano emergency-response planning and preparedness exercises?

- Do emergency responders conduct practice drills to simulate how they would respond to a volcanic eruption?

- Does the public participate in such drills?

- Can the hazard-zoning concept used for earthquake hazard mitigation in California be used for volcano hazards?

- How much warning will we get with a good network?

3. What is your understanding of the volcano hazards, and the vulnerability to these hazards, in your community or jurisdiction?

- Volcano hazards in California are related to several well-known volcanic centers, which are fortunately distant from the main population centers, but could impact populated areas and important infrastructure.

4. Does your agency have a volcano crisis coordination or response plan, or is it part of a multiagency plan? Are you familiar with the plan?
- CGS has a volcano emergency-response plan, part of our overall geologic emergency-response plan. We've just revised that and I am familiar with it.

5. How would a sudden-onset volcano crisis in your "backyard" be managed? Would it be a multiagency effort? How are multiagency efforts coordinated where you work?

- CGS response would be in cooperation with USGS and coordinated through Cal OES-the emergencyresponse plan gives a basic outline of roles and responsibilities.

6. From an emergency-management and safety perspective, what do you see as unique about volcanic activity in comparison with other hazards?

- Volcanic activity can come with days/weeks of warning, similar to flood or landslide hazards but different from earthquakes.

- Volcanic activity can continue for months/years, much longer than the time scale of other geologic hazards.

- Volcanic activity can produce a level of devastation only approached by tsunamis.

\section{U.S. Delegate Response 2}

1. What specific insights do you hope to gain from this trip?

- Greater understanding of types of preparedness awareness performed prior to eruptions.

- More information on risk management decisionsvalues considered and planning process.

2. List three questions that YOU want to see answered concerning effective volcano response.

- Who [should make up] the best team to involvekey skills needed?

- How is information shared with different stakeholders?

- What are the next steps after a response-rebuilding and sharing information?

3. What is your understanding of the volcano hazards, and the vulnerability to these hazards, in your community or jurisdiction? 
- I have been learning of the hazards in my community over the years; I am familiar with USGS CalVO and status of Mount Shasta. I have read and reviewed the Siskiyou County general plan on volcanic hazards and their assessment.

4. Does your agency have a volcano crisis coordination or response plan, or is it part of a multiagency plan? Are you familiar with the plan?

- No specific plan in place. Opportunities exist to use our existing multi-agency groups to develop and coordinated an appropriate response.

5. How would a sudden-onset volcano crisis in your "backyard" be managed? Would it be a multiagency effort? How are multiagency efforts coordinated where you work?

- Multiagency. With our history of large fires in the north part of the State, I think we have good communication bout our level of preparedness is low.

6. From an emergency-management and safety perspective, what do you see as unique about volcanic activity in comparison with other hazards?

- Duration. We are uncertain of NEXT stops following volcanic activity and exactly how to ensure emergency management and safety are maintained over time.

\section{U.S. Delegate Response 3}

1. What specific insights do you hope to gain from this trip?

- Ideas on indicators of warning.

- How early is too early and how late is too late?

- Emergency response and planning that relate to all all-risk emergency scenarios?

2. List three questions that YOU want to see answered concerning effective volcano response.

- Possible initial extent of effective area?

- Long-term effects?

- USGS (?) response time?

3. What is your understanding of the volcano hazards, and the vulnerability to these hazards, in your community or jurisdiction?

- Limited understanding to volcanic hazards, specifically with knowledge of natural disaster hazards (particularly wildfire). I do believe Mammoth Lakes and surrounding communities are vulnerable to hazards associated with evacuations and environmental impacts.

4. Does your agency have a volcano crisis coordination or response plan, or is it part of a multiagency plan? Are you familiar with the plan?

- I am not totally familiar with the volcano response plan. A volcanic eruption and associated response would definitely be/require a multiagency response.

5. How would a sudden-onset volcano crisis in your "backyard" be managed? Would it be a multiagency effort? How are multiagency efforts coordinated where you work?

- Management would definitely be multiagency. Multiagency all-risk teams already exist and are continuously being built, coordinated, and improved upon. The [multiagency partners] along the Eastern Sierra have had recent events (wildfires) to refine coordination between incident management teams and emergency operation centers.

6. From an emergency-management and safety perspective, what do you see as unique about volcanic activity in comparison with other hazards?

- Every all-risk incident provides unique circumstances every time. I would think the initial response would create similar safety concerns as other incidents, that is, evacuation, exclusion zones, and long-range planning. Expertise in volcanism would be a unique and mandatory requirement. Long-rang planning and understanding of future or lasting hazards would be unique compared to wildfires.

\section{U.S. Delegate Response 4}

1. What specific insights do you hope to gain from this trip?

- What caught emergency managers by surprise, other than the volcano?

- How are they dealing with the resettlement issue and future emergency preparedness?

2. List three questions that YOU want to see answered concerning effective volcano response.

- What were unexpected problems during emergency management of eruptive/evacuation phase?

- How did you keep the first responders safe? What were identified as risks for the emergency response teams? 
- How did you deal with at-risk special-needs populations?

3. What is your understanding of the volcano hazards, and the vulnerability to these hazards, in your community or jurisdiction?

- Mostly denial of any real risk. It's such a far-off possibility that almost no one takes it very seriously. Certainly a poor understanding of risk to the shortterm visiting public; the volcano shifting to a more eruptive phase would be an attractor, bringing people the area as spectators.

4. Does your agency have a volcano crisis coordination or response plan, or is it part of a multiagency plan? Are you familiar with the plan?

- Lassen Volcanic NP has a comprehensive emergency operations plan that encompasses a volcanic eruption, as well as a number of other events such as wildland fire, severe storms, long-duration power outages, etc.

- Plan consists of 3 distinct elements: emergency command and control procedures, evacuation, and continuity of operations. I wrote the plan.

5. How would a sudden-onset volcano crisis in your "backyard" be managed? Would it be a multiagency effort? How are multiagency efforts coordinated where you work?

- Lassen Volcanic National Park sits right in the middle of four counties. A volcanic crisis would very much be a multiagency endeavor. Joint training and table top exercises have helped. SAR [search and rescue] coordinator meetings with various counties, other jurisdictions (Cal OES). Still always a challenge, for example key people come and go, protocols change, sheriffs are elected officials, etc.

6. From an emergency-management and safety perspective, what do you see as unique about volcanic activity in comparison with other hazards?

- The potential scope of disruption.

- The length of disruption.

- Potential for major impacts to vital economic centers and infrastructure-I -5 corridor, irrigation canals, major portions of the power grid, major natural gas pipelines, plus tourism and impacts to native salmon and steelhead spawning habitat.

\section{U.S. Delegate Response 5}

1. What specific insights do you hope to gain from this trip?

- If/how Chile assesses and communicates community exposure, sensitivity, and resilience to hazards.

- How community evacuation decisions are made.

- How Chilean authorities communicate threats, evacuation orders, and return to normalcy.

2. List three questions that YOU want to see answered concerning effective volcano response.

- What plans exist to help vulnerable populations?

- Do response plans take into account community quality of life and continuity?

- How do they decide when to evacuate communities and who makes the decision? Are communities part of the decision process?

3. What is your understanding of the volcano hazards, and the vulnerability to these hazards, in your community or jurisdiction?

- Not exactly applicable since I don't have a community or jurisdiction at risk. But I do have a good sense of societal exposure to CA volcanoes.

4. Does your agency have a volcano crisis coordination or response plan, or is it part of a multiagency plan? Are you familiar with the plan?

- Yes, USGS is involved in multiagency planning.

5. How would a sudden-onset volcano crisis in your "backyard" be managed? Would it be a multiagency effort? How are multiagency efforts coordinated where you work?

- USGS works with local, State, and Federal partners.

6. From an emergency-management and safety perspective, what do you see as unique about volcanic activity in comparison with other hazards?

- The long run-up to catastrophic events.

- The long-term nature of the hazards.

- The regional and indirect nature of impacts. 


\section{U.S. Delegate Response 6}

1. What specific insights do you hope to gain from this trip?

- As a response lead for the department, I hope to gain insight on how we can support local jurisdictions with volcanic threats in mitigation planning to further enhance preparedness, response, and recovery.

2. List three questions that YOU want to see answered concerning effective volcano response.

- What are the toughest challenges officials have faced in working with volcanic hazards and how are they being addressed?

- What are the protocols for volcanic hazard notification, alerting, and evacuation?

-What community engagement is done to help people understand potential volcanic hazards?

3. What is your understanding of the volcano hazards, and the vulnerability to these hazards, in your community or jurisdiction?

- This is not my area of expertise, and I hope to gain from this delegation experience a greater understanding of how to support the planning, response, and recovery efforts to volcanic hazards in California.

4. Does your agency have a volcano crisis coordination or response plan, or is it part of a multiagency plan? Are you familiar with the plan?

- During FY15-16 staff will work with USGS to continue development of the volcano hazard-specific appendix to the State Emergency Plan. This appendix will summarize the volcanic hazards and the threats they pose to people, property, environment, and the economy.

5. How would a sudden-onset volcano crisis in your "backyard" be managed? Would it be a multiagency effort? How are multiagency efforts coordinated where you work?

- As in other emergencies we would use our SEMS [Standardized Emergency Management System], which would lead to a multiagency effort. Our Southern Region EOC would be activated along with the State Operations Center to coordinate mutual aid.

6. From an emergency-management and safety perspective, what do you see as unique about volcanic activity in comparison with other hazards?

- The capability to forewarn those in an impact area in order to minimize loss of life. Unlike other no-notice events, such as earthquakes, early notification due to the probability of an eruption can be significant in preserving the safety of a population.

\section{U.S. Delegate Response 7}

1. What specific insights do you hope to gain from this trip?

- Solutions for foreign language residents and visitors.

- Issues that SERNAGEOMIN faces with education, alert response or lack thereof, and monitoring network issues.

- Things we can learn from their techniques.

2. List three questions that YOU want to see answered concerning effective volcano response.

- Maintain hazard warning signs on public lands.

- Refresh and update response plans for towns and public lands with potential hazards.

- Don't hide the "volcano."

3. What is your understanding of the volcano hazards, and the vulnerability to these hazards, in your community or jurisdiction?

- Ash hazards, lahar/mudflow hazards, small but potential explosive hazards.

- Lots of visitors that may not be aware of the hazards.

- Foreign populations, older populations, and people with special needs.

- Not many back-up road systems.

4. Does your agency have a volcano crisis coordination or response plan, or is it part of a multiagency plan? Are you familiar with the plan?

- CalVO has a response plan for the Long Valley and Mammoth Lakes areas, but it needs updating. The plan has been incorporated into Mono County and Inyo County response plans. Not sure of other volcanic areas.

5. How would a sudden-onset volcano crisis in your "backyard" be managed? Would it be a multiagency effort? How are multiagency efforts coordinated where you work?

- A sudden onset crisis would be a multiagency effort - most likely with an EOC or Unified Command. Scientists would provide data and activity alert level information to emergency response man- 
agers, most likely USFS, sheriff, and local government.

6. From an emergency-management and safety perspective, what do you see as unique about volcanic activity in comparison with other hazards?

- Potential long-lasting effects.

- Activity levels can increase suddenly and lead to eruption [, but an eruption might not occur despite precursory signals].

- Public is generally complacent and not always [ready to respond].

\section{U.S. Delegate Response 8}

1. What specific insights do you hope to gain from this trip?

- Strategies and ideas of evacuations of large numbers of people from hazard zones.

- Best practices and lessons learned from real-world experiences in Chile.

2. List three questions that YOU want to see answered concerning effective volcano response.

- How to best communicate hazards with tourist/transient populations?

- Estimated timeframes for repopulation of affected areas?

- Major risks to responders and ways to quickly mitigate responder risks during evacuation process?

3. What is your understanding of the volcano hazards, and the vulnerability to these hazards, in your community or jurisdiction?

- Yosemite/Mammoth areas seem more concerned with earthquake, flood, or fire threats. General misunderstanding that volcano hazards are not overly high in the Sierra.

- Overall evacuation planning is occurring in Yosemite and with surrounding communities that could be adapted for volcano hazards.

4. Does your agency have a volcano crisis coordination or response plan, or is it part of a multiagency plan? Are you familiar with the plan?

- Yosemite National Park is working on a broad evacuation plan for the park with specific appendices for various hazards.
- Devils Postpile National Monument is working with an interagency team and hopes to create a better response plan.

5. How would a sudden-onset volcano crisis in your "backyard" be managed? Would it be a multiagency effort? How are multiagency efforts coordinated where you work?

- Most likely modeled after large-scale wildland fire responses that have occurred in previous years. Interagency effort would be coordinated using the ICS system and most likely a unified command.

6. From an emergency-management and safety perspective, what do you see as unique about volcanic activity in comparison with other hazards?

- Some of the threats from volcanic activity are not readily seen as dangerous (that is, slow moving lava flow) or are not visible to populations at risk (that is, lahars can impact towns a long distance away, ashfall can impact areas even farther away).

\section{U.S. Delegate Response 9}

1. What specific insights do you hope to gain from this trip?

- During the trip, I hope to better understand emergency management through disasters such as those caused by volcanoes - how to plan, prepare, and recover from such disasters. I am also increasingly interested in fostering a line of communication between Cal OES and our ONEMI counterparts.

2. List three questions that YOU want to see answered concerning effective volcano response.

- What is the volcano preparedness platform and approach? Is it consistent throughout the regions and country?

- What is the frequency and method (written, radio, television) of reaching the population with a preparedness message?

- Is volcano preparedness/volcano education taught in schools, if so at what levels (for example, primary or secondary)?

3. What is your understanding of the volcano hazards, and the vulnerability to these hazards, in your community or jurisdiction?

- I recently learned that there are eight volcanoes varying from very high to low threat levels in California, which that are presently on the watch list. 
- Volcano hazard zones cover roughly 24,000 square miles in California and impact and cross 10 counties.

- Approximately 190,000 residents live in volcano hazard zones, and can be affected by the initial eruption, volcanic ash, pyroclastic flows, and lava and mudflows.

4. Does your agency have a volcano crisis coordination or response plan, or is it part of a multiagency plan? Are you familiar with the plan?

- For volcano emergencies, Cal OES operates according to the following plans:

- State Emergency Plan.

- Joint Cal OES-FEMA Catastrophic Incident Base Plan.

5. How would a sudden-onset volcano crisis in your "backyard" be managed? Would it be a multiagency effort? How are multiagency efforts coordinated where you work?

- As with all emergencies in California, disasters are first attacked at the local level. Yet, it is a multiagency effort in that other agencies assist local agencies when these agencies have exhausted their aid. When higher-level State agencies deplete their resources, only then are Federal agencies called upon to supply any remaining assistance.

6. From an emergency-management and safety perspective, what do you see as unique about volcanic activity in comparison with other hazards?

- What I believe to be unique about volcanic activity is the level of air pollution that it can leave behind, even months and years after the disaster has occurred. As with earthquakes and tsunamis, there may be a lot of infrastructure damage to repair, but the air quality caused by a volcanic eruption may be more difficult to remedy.

\section{Chilean Delegate Responses to California Pretrip Questionnaire}

\section{Chilean Delegate Response 1}

1. What specific insights do you hope to gain from this trip? ¿Cuáles ideas específicas qué esperes ganar de este viaje?

- Conocimiento y comunicación con personas. Knowledge and communication with people.
- Tecnologías y estrategias asociadas al manejo del riesgo. Technologies and strategies associated with managing risk.

- Sistemas de información Geográfica, modelación de riesgos y amenazas. GIS systems; modeling risks and hazards.

2. List three questions that YOU want to see answered concerning effective volcano response. ¿Qué son tres preguntas que quieres ver contestado sobre las respuestas eficaces a las erupciones volcánicas?

- Forma de llegar con la alarma a la comunidad y sus tiempos de respuesta. How to facilitate alarms for communities and their response times.

- Tratamiento de comunicación con las personas y su relación con las autoridades. How communication with people in communities is done, and how they relate to the authorities.

- Estrategias de preparación, educación y entrenamiento a la comunidad. Strategies for preparation, education, and training people in communities.

3. What is your understanding of the volcano hazards, and the vulnerability to these hazards, in your community or jurisdiction? ¿Cuál es tu comprensión de los peligros volcánicos y la vulnerabilidad a estos peligros, en tu comunidad o jurisdicción?

- Como Director Regional de ONEMI, es amplia y especifica respecto de cada comunidad, no obstante esta se logra por medio de la asociación directa con los entes TECNICOS, como SERNAGEOMIN. As a Regional Director of ONEMI, my understanding is broad and specific for each community [in my region]. However, this is achieved through direction association with technical entities such as SERNAGEOMIN.

4. Does your agency have a volcano crisis coordination or response plan, or is it part of a multiagency plan? Are you familiar with the plan? ¿Tiene tu agencia un plan de coordinación o de respuesta a la crisis de "tu" volcán, o es parte de un plan multi-agencia? ¿Estás familiarizado con el plan?

- Estamos preparando un plan por parte de cada comunidad respecto de su propio Volcán, iniciamos una fase previa de conocimiento, directamente con la propia comunidad y difusión de las características de cada uno de ellos, les proporcionamos la señalética y seguidamente los preparamos para elaborar su propio plan, para finalmente entrenar con la comunidad ese plan. We are preparing a plan for each community with respect to its own volcano. We are initiating 
a preliminary education outreach directly to each community in accordance with its particular needs. We provide signage and prepare them for developing their own plans, and finally we train the community on putting the plan into action.

5. How are multiagency efforts coordinated where you work? ¿Cómo están los esfuerzos de múltiples agencias coordinadas en la que trabajas?

- Están bien, pero se debe seguir trabajando coordinadamente, en las diferentes etapas de la emergencia y con objetivos comunes. They are fine, but working together in concert should continue for each of the different stages of an emergency to further the goals of the community.

6. From an emergency-management and safety perspective, what do you see as unique about volcanic activity in comparison with other hazards? Desde una perspectiva de gestión de emergencias y seguridad, ¿qué ves como único acerca de la actividad volcánica en comparación con otros riesgos?

- Que lo conocemos, sobemos donde esta y lo podemos seguir. We know it, we know where it is, and we can follow.

\section{Chilean Delegate Response 2}

1. What specific insights do you hope to gain from this trip? ¿Cuáles ideas específicas qué esperes ganar de este viaje?

- Learn how communities are educated in terms of natural hazards.

- How civil authorities can manage exclusion zones when the natural hazards occurrence is difficult to forecast in the long term.

- Hazard management plans during natural crises, involving different agencies.

2. List three questions that YOU want to see answered concerning effective volcano response. ¿Qué son tres preguntas que quieres ver contestado sobre las respuestas eficaces a las erupciones volcánicas?

- What are the criteria for changing volcanic alert levels under volcanic unrest (either due to increase or decrease of volcanic activity)?

- How are the volcanic alert levels (defined by the volcano observatory) compared to the emergency office alert levels?

- Who is responsible for informing communities about volcanic unrest and potential evacuations?
3. What is your understanding of the volcano hazards, and the vulnerability to these hazards, in your community or jurisdiction? ¿Cuál es tu comprensión de los peligros volcánicos y la vulnerabilidad a estos peligros, en tu comunidad o jurisdicción?

- I do have a good understanding of volcano hazards in my community, which corresponds to Temuco city in the central valley. Those are mostly related to fine ash fallout during explosive eruptions (however, low accumulation on the surface is expected) and impacts derived from extreme (low probability) events, such as distal facies of large ignimbrites that occurred in the past 10,000 years (for example, derived from Llaima and Villarrica volcanoes). Owing to the type of volcanic phenomena indicated and their recurrence, the vulnerability of Temuco city to volcano hazards is low.

4. Does your agency have a volcano crisis coordination or response plan, or is it part of a multiagency plan? Are you familiar with the plan? ¿Tiene tu agencia un plan de coordinación o de respuesta a la crisis de "tu" volcán, o es parte de un plan multi-agencia? ¿Estás familiarizado con el plan?

- During volcanic unrest, internal meetings at SERNAGEOMIN are held to evaluate the status of the volcano activity according to monitoring parameters. These meetings are technical, including geologists and geophysicists. Occasionally, SERNAGEOMIN higher authorities are involved (national director and (or) national head of geology (Subdirector de Geología)).

- If the volcano alert level will be changed - based on technical criteria - an official report is sent to several authorities in the country, including the National Emergency Office (ONEMI).

- If a volcanic crisis occurs, coordination meetings are held, including both regional and national authorities. The focus is the evaluation of volcano hazards, their extent, and which actions must be taken to ensure the safety of people and infrastructure.

5. How are multiagency efforts coordinated where you work? ¿Cómo están los esfuerzos de múltiples agencias coordinadas en la que trabajas?

- As described above, during volcanic crises there is a close relation with other agencies, in particular with ONEMI and local governments.

- During non-unrest time, some activities are usually done to inform people about volcano hazards and geological evolution. However, these are mostly based on individual interest rather than multiagency coordination. 
6. From an emergency-management and safety perspective, what do you see as unique about volcanic activity in comparison with other hazards? Desde una perspectiva de gestión de emergencias y seguridad, ¿qué ves como único acerca de la actividad volcánica en comparación con otros riesgos?

- In some aspects, it is hard to evaluate volcano hazards based not only on the recorded history of past events (during historical times). For example, the effect of pyroclastic flows that have reached populated areas in the geological record cannot be fully understood. This can be a problem for mitigation plans.

- Another unique aspect is the uncertainty related to eruption forecast. At the moment, I see that forecasting volcanic unrest works pretty well in most cases, but on the other hand, it is much more difficult to forecast eruption size and duration, or even the potential extension of the products. Not to mention that volcanic unrest might not be an indication of eruptive activity necessarily.

- Finally, hazards such as ashfall or distal lahars might impact areas faraway from volcanoes, where communities are not used to volcanic phenomena.

\section{Chilean Delegate Response 3}

1. What specific insights do you hope to gain from this trip? ¿Cuáles ideas específicas qué esperes ganar de este viaje?

- I want to get some ideas about how to create a volcanic emergency plan for the park. I want to know the concepts included in an emergency plan.

- I hope to learn some tools for good alert communication and coordination with public services and what kind of communications system is necessary in the park for a good alert system.

2. List three questions that YOU want to see answered concerning effective volcano response. ¿Qué son tres preguntas que quieres ver contestado sobre las respuestas eficaces a las erupciones volcánicas?

- How expensive is the implementation of an effective early alert system in a national park?

- What kind of devices and instruments do you need for an effective early alert system in a national park?

- How does the method work to make the system effective for visitors?
3. What is your understanding of the volcano hazards, and the vulnerability to these hazards, in your community or jurisdiction? ¿Cuál es tu comprensión de los peligros volcánicos y la vulnerabilidad a estos peligros, en tu comunidad o jurisdicción?

- I know about the volcanoes' locations. I know different kinds of possible damages and effects on the visitors, workers, communities and infrastructure.

4. Does your agency have a volcano crisis coordination or response plan, or is it part of a multiagency plan? Are you familiar with the plan? ¿Tiene tu agencia un plan de coordinación o de respuesta a la crisis de "tu" volcán, o es parte de un plan multi-agencia? ¿Estás familiarizado con el plan?

- No, we don't have a response plan and we are not part of a multiagency plan.

5. How are multiagency efforts coordinated where you work? ¿Cómo están los esfuerzos de múltiples agencias coordinadas en la que trabajas?

- Well, I think we are working on that. This internship is a big step. But, we are giving some support to SERNAGEOMIN with the access to the land around the volcanoes in the area, and we are giving them some Internet support for sending data. SERNAGEOMIN has given a couple of workshops to the Pumalín Park ranger team; thanks to that, our team knows more about the volcanoes and their hazards.

6. From an emergency-management and safety perspective, what do you see as unique about volcanic activity in comparison with other hazards? Desde una perspectiva de gestión de emergencias y seguridad, ¿qué ves como único acerca de la actividad volcánica en comparación con otros riesgos?

- The singularities are how powerful it is, the magnitude, and the unexpected impacts.

\section{Chilean Delegate Response 4}

1. What specific insights do you hope to gain from this trip? ¿Cuáles ideas específicas qué esperes ganar de este viaje?

- Conocer los centros encargados del monitoreo volcánico y eventualmente sísmico de California y su relación con estados unidos. Know the facilities responsible for volcanic and possibly seismic monitoring in California and its relationship with monitoring by the United States. 
- Intercambio de experiencias de los científicos de EEUU y de Chile, para determinar semejanzas, diferencias y cómo mejorar en Chile. Sharing experiences of scientists from the United States and Chile, to determine similarities, differences and how to improve things in Chile.

- Visitar zonas volcánicas. Visit volcanic zones.

- Ver la preparación de la población respecto a emergencias volcánicas. See how populations are prepared for volcanic emergencies.

2. List three questions that YOU want to see answered concerning effective volcano response. ¿Qué son tres preguntas que quieres ver contestado sobre las respuestas eficaces a las erupciones volcánicas?

- ¿Cómo determinan las áreas de peligro volcánico? How are volcanic hazard zones determined?

- ¿Cómo influyen los instrumentos de planificación territorial en las zonas de riesgo? How do local planning procedures influence hazard zones?

- ¿Cómo se prepara la población para las emergencias volcánicas, quién les enseña y cómo se entrega la alerta a la población? How is the population prepared for volcanic emergencies, who teaches them, and how is the alert transmitted to the population?

3. What is your understanding of the volcano hazards, and the vulnerability to these hazards, in your community or jurisdiction? ¿Cuál es tu comprensión de los peligros volcánicos y la vulnerabilidad a estos peligros, en tu comunidad o jurisdicción?

- La ciudad de Santiago se encuentra en la Región Metropolitana, donde se encuentran algunos volcanes activos. The city of Santiago is located in a metropolitan region, where there are several active volcanoes.

- Sernageomin ha elaborado cartas de peligros volcánicos, considerando área de caída de piroclástos, lahares y cenizas. SERNAGEOMIN has prepared charts about volcano hazards, considering the areas subject to pyroclastic fall, lahars, and ash.

- ONEMI entrega recomendaciones en general sobre qué debe hacer la población ante una emergencia volcánica. ONEMI delivers general recommendations on what a community should do to prepare for a volcanic emergency.

4. Does your agency have a volcano crisis coordination or response plan, or is it part of a multiagency plan? Are you familiar with the plan? ¿Tiene tu agencia un plan de coordinación o de respuesta a la crisis de "tu" volcán, o es parte de un plan multi-agencia? ¿Estás familiarizado con el plan?

- ONEMI tiene folletos con recomendaciones de erupciones volcánicas en general, no existe para cada volcán. ONEMI has brochures with recommendations about volcanic eruptions in general.

- Las comunas, cuentan con un plan de emergencia para su respectivo volcán, pero es de conocimiento de sus habitantes y no de la población en general. The towns rely on emergency plans for their respective volcanoes, but it is local knowledge that is not understood by the general population.

- El plan de emergencia del volcán incluye la información de peligros volcánicos elaborada por Sernageomin. The volcano emergency plan includes information about volcano hazards, which is produced by SERNAGEOMIN.

5. How are multiagency efforts coordinated where you work? ¿Cómo están los esfuerzos de múltiples agencias coordinadas en la que trabajas?

- Existe coordinación entre ONEMI, encargada de la protección civil y Sernageomin, encargado de estudiar e informar los peligros volcánicos. There is coordination between ONEMI, which is responsible for civil protection, and SERNAGEOMIN, which is responsible for studying and providing information about volcano hazards.

- ONEMI y Sernageomin tienen un protocolo, donde se indican las responsabilidades de cada uno en caso de emergencia. ONEMI and SERNAGEOMIN have a protocol that indicates the responsibilities of each agency in case of an emergency.

6. From an emergency-management and safety perspective, what do you see as unique about volcanic activity in comparison with other hazards? Desde una perspectiva de gestión de emergencias y seguridad, ¿qué ves como único acerca de la actividad volcánica en comparación con otros riesgos?

- Existe capacidad para determinar anticipadamente una alerta temprana para las erupciones volcánicas porque Sernageomin tiene una gran red de instrumentos científicos para el monitoreo volcánico. The ability exists to produce early warnings of volcanic eruptions, because SERNAGEOMIN has a large network of scientific instruments to monitor volcanoes. 


\section{Chilean Delegate Response 5}

1. What specific insights do you hope to gain from this trip? ¿Cuáles ideas específicas qué esperes ganar de este viaje?

- Conocer CalVO para ayudar a modelar el desarrollo del futuro Observatorio Volcanológico de los Andes Australes, conocer la manera de procesar datos, de estándares internacionales y la vinculación con las demás instituciones antes, durante y después de una crisis volcánica. To learn about CalVO in order to help shape the development of the future Southern Andes Volcano Observatory, to learn how data are processed, to learn about international standards, and to learn how other institutions are linked before, during, and after a volcanic crisis.

- Conocer otros estudios que se realizan en volcanes y que, tal vez, no realizamos en Chile. To know about other studies that are carried out at volcanoes, which perhaps are not conducted in Chile.

- Conocer una rápida discriminación de sismos volcánicos v/s sismos de glaciares. To learn a method of rapidly discriminating between volcanic earthquakes and glacier quakes.

2. List three questions that YOU want to see answered concerning effective volcano response. ¿Qué son tres preguntas que quieres ver contestado sobre las respuestas eficaces a las erupciones volcánicas?

- ¿Cómo se coordinan las acciones frente a una erupción; desde lo técnico hasta las decisiones de los organismo de Protección Civil? How is [information about] eruptive precursory activity coordinated with civil protection agencies?

- ¿Cuál es la dinámica antes y durante una crisis volcánica al interior del CalVO? What are the dynamics within CalVO before, during, and after an eruption?

- ¿Cómo han logrado una estandarización en la adquisición y en compartir datos desde distintas instituciones, universidades o servicios? How has standardization in the acquisition and sharing of data been achieved between different institutions, universities, and agencies?

3. What is your understanding of the volcano hazards, and the vulnerability to these hazards, in your community or jurisdiction? ¿Cuál es tu comprensión de los peligros volcánicos y la vulnerabilidad a estos peligros, en tu comunidad o jurisdicción?

- Muy buena, conozco los distintos productos volcánicos predominantes de los distintos edificios volcánicos cercanos a mi ciudad; también se de la afectación de los mismos, debido a que, por mi profesión (Geólogo) he participado en la confección de los planes de evacuación ante emergencias volcánicas (junto a diversas instituciones, fuerzas armadas y servicios de mi región). También, cuando estoy en terreno reconozco depósitos y transmito de esos hallazgos a los colegas que trabajan en la confección de mapas de peligros. Very good. I know the different predominant volcanic products of various volcanoes near my city; I am involved in this because of my profession (geologist). I have participated in the preparation of volcanic emergency evacuation plans (together with various institutions, the armed forces and agencies in my area). When I'm on the ground I also recognize deposits and transmit these findings to colleagues working in the mapping of hazards.

4. Does your agency have a volcano crisis coordination or response plan, or is it part of a multiagency plan? Are you familiar with the plan? ¿Tiene tu agencia un plan de coordinación o de respuesta a la crisis de "tu" volcán, o es parte de un plan multi-agencia? ¿Estás familiarizado con el plan?

- $\mathrm{Si}$, existen protocolos basados en la actividad sísmica de los volcanes al interior de SERNAGEOMIN; también hay coordinación a nivel nacional y la región tiene su propio Plan de Emergencia. Estoy familiarizado con los planes. Yes, protocols exist, based on volcanic seismic activity, within SERNAGEOMIN. There is also coordination at the national regional level, and the region has its own plan. I am familiar with the plans.

5. How are multiagency efforts coordinated where you work? ¿Cómo están los esfuerzos de múltiples agencias coordinadas en la que trabajas?

- Las coordinaciones con otras instituciones presentes en la región, se realizan mediante el COE (Comité Operativo de Emergencias) y son efectivas. Coordination among other institutions present in the region is carried out by the COE (Emergency Operations Committee), and it is effective.

6. From an emergency-management and safety perspective, what do you see as unique about volcanic activity in comparison with other hazards? Desde una perspectiva de gestión de emergencias y seguridad, ¿qué ves como único acerca de la actividad volcánica en comparación con otros riesgos?

- Caída de cenizas en mi ciudad; ocurrencia de lahares en zonas cercanas al volcán; remociones en masa en toda la región. Ashfall in my city, the occurrence of lahars near the volcano, and mass removals [landslides/debris flows] throughout the region. 


\section{Chilean Delegate Response 6}

1. What specific insights do you hope to gain from this trip? ¿Cuáles ideas específicas qué esperes ganar de este viaje?

- To know about experiences in crisis response in U.S.A.; the relationships among scientists, emergency responders, authorities, and the media.

2. List three questions that YOU want to see answered concerning effective volcano response. ¿Qué son tres preguntas que quieres ver contestado sobre las respuestas eficaces a las erupciones volcánicas?

- How you in U.S.A. distinguish technical alerts issued by USGS from civil protection alerts?

- How do you manage the competing authorities at Federal, State, and national levels?

- How deep do you go with science into the emergency response in terms of basic information and technical advice?

3. What is your understanding of the volcano hazards, and the vulnerability to these hazards, in your community or jurisdiction? ¿Cuál es tu comprensión de los peligros volcánicos y la vulnerabilidad a estos peligros, en tu comunidad o jurisdicción?

- Poor in general, but growing fast.

4. Does your agency have a volcano crisis coordination or response plan, or is it part of a multiagency plan? Are you familiar with the plan? ¿Tiene tu agencia un plan de coordinación o de respuesta a la crisis de "tu” volcán, o es parte de un plan multi-agencia? ¿Estás familiarizado con el plan?

- We at SERNAGEOMIN are part of the Civil Protection System, which is itself a multiagency scheme.

5. How are multiagency efforts coordinated where you work? ¿Cómo están los esfuerzos de múltiples agencias coordinadas en la que trabajas?

- There is a committee for coordination, but in my opinion the mix between representatives of the agencies and scientists who act as individuals is not good enough.

6. From an emergency-management and safety perspective, what do you see as unique about volcanic activity in comparison with other hazards? Desde una perspectiva de gestión de emergencias y seguridad, ¿qué ves como único acerca de la actividad volcánica en comparación con otros riesgos?
- There are a number of common features, perhaps the media attention being a very big issue.

\section{Chilean Delegate Response 7}

1. What specific insights do you hope to gain from this trip? ¿Cuáles ideas específicas qué esperes ganar de este viaje?

- Conocer como se implementan los mapas de riesgos en EEUU (por ejemplo HAZUS). To learn how risk maps are implemented in the United States (for example, HAZUS).

- Conocer cómo se integra a la comunidad en la alerta temprana. To learn how [risk maps] are used by communities for early warnings.

- Y como se integra el trabajo que realiza USGS a las organizaciones de respuesta. And to learn how work done by the USGS is integrated with the work of response organizations.

2. List three questions that YOU want to see answered concerning effective volcano response. ¿Qué son tres preguntas que quieres ver contestado sobre las respuestas eficaces a las erupciones volcánicas?

- ¿Cómo se dio la alerta? How are alerts given?

- ¿Cómo se preparan para realizar evacuaciones? What is done to prepare for evacuations?

- ¿Cómo es el retorno de la comunidad, luego de pasada la emergencia? How is the return of communities [to hazard zones] handled following an emergency?

3. What is your understanding of the volcano hazards, and the vulnerability to these hazards, in your community or jurisdiction? ¿Cuál es tu comprensión de los peligros volcánicos y la vulnerabilidad a estos peligros, en tu comunidad o jurisdicción?

- En mi comunidad inmediata no existen riesgos volcánicos, para Chile sin embargo el tema es relevante y diría que la comunidad no entiende aun como convivir con las amenazas volcánicas, cuales son los sistemas de alerta. In my immediate community there are no volcano hazards; for Chile, however, the topic is relevant and one could say that the population does not understand yet lives with volcano hazards and warning systems.

4. Does your agency have a volcano crisis coordination or response plan, or is it part of a multiagency plan? Are you familiar with the plan? ¿Tiene tu agencia un plan de 
coordinación o de respuesta a la crisis de "tu" volcán, o es parte de un plan multi-agencia? ¿Estás familiarizado con el plan?

- Not applicable.

5. How are multiagency efforts coordinated where you work? ¿Cómo están los esfuerzos de múltiples agencias coordinadas en la que trabajas?

- Not applicable.

6. From an emergency-management and safety perspective, what do you see as unique about volcanic activity in comparison with other hazards? Desde una perspectiva de gestión de emergencias y seguridad, ¿qué ves como único acerca de la actividad volcánica en comparación con otros riesgos?
- Me parece que hay conocimiento científico que se ha generado, hay análisis histórico de erupciones volcánicas, es un fenómeno que se ha estudiado y por lo mismo, se puede explicar a la comunidad. It seems that there is scientific knowledge that has been generated, there are historical analyses of volcanic eruptions, and it is a phenomenon that has been studied. Therefore, it can be explained to the community.

- Los volcanes son un importante elemento del paisaje en Chile y pese a ello y al conocimiento científico existente no toda la población sabe como convivir con ellos. Volcanoes are an important element of the Chilean landscape, and despite that and the existing knowledge, not all the population knows how to live with them. 


\section{Appendix 2. Posttrip Questionnaires}

\section{U.S. Delegate Responses to Chile Posttrip Questionnaire}

\section{U.S. Delegate Response 1}

1. What key insights have you gained from the visit to Chile (from a broad perspective)?

- I was incredibly impressed by the amount of work being done in Chile related to hazard monitoring, education, and response with a very small amount of staff in comparison to the United States. We are lucky to have the people and funding to have developed/specialized programs and operations in the United States. Although we have a lot of expertise in planning for events, Chile has had (and is still having) direct experience dealing with a huge variety of hazard response, including from floods, tsunamis, earthquakes, fires, volcanoes, landslides. Tabletop exercises and drills just can't compare with living and dealing with the real thing.

2. Name three specific changes that you will try to apply personally within the scope of your job, based on what you have learned. Do you see barriers to their implementation?

- The need for technical expertise to be included in the ICS system during disaster response. The only barrier to this would be having those contacts preestablished so that you know who to call immediately when the incident management team is not from the local area. Knowing that the incident management team I am on will likely be deployed if a volcanic crisis affects any Western parks, I feel like I now have a contact list that includes people who will be able to immediately get me quality information, as well as technical expertise.

- Increased collaboration with local experts related to volcano hazards my park faces. The major barrier to this is that like Chile, Yosemite has a wide range of potential hazards - drought, fire, winter storms, floods, and rockfall. Presenting a new hazard without it getting lost in all of the emergency education information can be a challenge.

- Provide Devils Postpile National Monument with oversight and assistance as they develop an evacuation plan.

3. Identify three key recommendations you would like to make to management within your agency to more effectively deal with a future volcano crisis at Long Valley. In other words, what changes would you like to see in the status quo?

- Integrate Yosemite National Park and the NPS into multiagency coordination for Long Valley. We will likely have less damage but be a huge resource during a volcanic crisis.

- Incident management training targeted for USGS technical specialists so they can be deployed during all risk responses and incorporated within the incident command structure.

- Volcano-hazard planning for parks should not only include monitoring and evacuation plans but repopulation plans and guidelines for dealing with secondary hazards, such as lahars, landslides, and ash. Plans should be created in consultation with technical specialists and park resource-management staff to address what if any reconstruction or ecosystem manipulation may or may not occur after the incident.

4. After seeing the situation in Chile, have your views on volcano hazards in California changed?

- I have always identified volcano hazards with the typical cone shaped snowy volcanoes of the [Pacific] Northwest. I learned a great deal about the hazards of Long Valley, which opened my eyes to the wide range of volcano hazards both in Chile and in the Western United States.

5. How could this exchange experience be improved? For example, please comment on logistics, number of delegates and expertise represented, delegate interactions, previsit briefings, or anything else?

- This was a great experience! The only thing I would have changed was the schedule. It seemed like many of the days were so packed with meetings and presentations (which were awesome!) that it left little time for reflection on what we were learning and discussing. One of the most meaningful experiences I had was sitting in Silvia's kitchen talking to her about the eruption and evacuation, which only occurred because we had decided not to have dinner! [Silvia was the proprietress of the small hotel where the delegates stayed.] A little more "downtime" could have allowed for more informal interactions like that. 


\section{U.S. Delegate Response 2}

1. What key insights have you gained from the visit to Chile (from a broad perspective)?

- Communications is key at all levels. Risk managers and scientists need to meet and discuss emergency planning and operations. Populations in towns located within hazard zones need to understand the risks and potential actions they can take in the lead up to an eruption. The importance of Federal officials meeting with local officials cannot be understated. Hazard maps should come as no surprise to anyone in affected communities. Expect politics to play a significant role in repopulation and posteruptive mitigation. Do not underestimate the public's emotional attachment to their homes and surrounding communities.

2. Name three specific changes that you will try to apply personally within the scope of your job, based on what you have learned. Do you see barriers to their implementation?

- Meet with Mineral [California] townsfolk to discuss the volcano and share hazard maps. Barriers include task management and always being called away to shorter-term issues, and indifference among people who do not see the volcano as much of a threat. Continue education efforts started by Maggie [Mangan] on volcanic crisis awareness among local first responders. Barriers include high agency turnover especially in key positions. Education and tabletop exercises need to be a continuing effort to combat high agency turnover. Complacency is a real barrier. Thirdly, start the discussion with our park superintendent on what he expects to do in rehabilitation of the park posteruption. It would be beneficial to have some of those conversations now and get the thought processes going.

3. Identify three key recommendations you would like to make to management within your agency to more effectively deal with a future volcano crisis at Long Valley. In other words, what changes would you like to see in the status quo?

- I am not sure what is going on right now in the Long Valley area. I will gain more insight once that part of the exchange is completed.

4. After seeing the situation in Chile, have your views on volcano hazards in California changed?

- We have it pretty good in the sense that our emergency management is much more integrated at the national, State and local levels to handle large-scale crisis. However, the Chileans have a lot more experience at it. Volcanoes seem to be erupting all the time there. My biggest worry on the U.S. side is complacency ... getting folks to realize there are issues and real concrete things they should do to prepare. We can expect a concerted effort to repair and repopulate any affected areas post eruption. We as a society will continue to rebuild in known hazard zones. Examples can be found everywhere from Hurricane Katrina, superstorm Sandy, and other such events.

5. How could this exchange experience be improved? For example, please comment on logistics, number of delegates and expertise represented, delegate interactions, previsit briefings, or anything else?

- Not much to be improved upon; delegation seemed to be a great mix of people. Pretrip briefing was outstanding. Well informed before leaving. Travel logistics were almost too nice. Only real improvement would be the ground transportation for the Temuco to Puerto Montt section. Pretty rough all being crammed in such small vans. Biggest pains were negotiating the bureaucracy of getting approvals to go, the long timelines needed to obtain an official passport, and complexities of the travel-voucher system upon return. It would be very beneficial to have a sample international travel voucher for travel folks to review, or someone who really knew the system to be available for support during the travelauthorization and travel-voucher process.

\section{U.S. Delegate Response 3}

1. What key insights have you gained from the visit to Chile (from a broad perspective)?

- Multihazards that the country experiences, with volcanos being a key hazard. The approach to managing various hazards with clear, outlined response plans.

- The importance of having a plan to engage volunteers and repopulation of a hazard area.

- The importance of supporting resiliency and engaging a community to be part of the response.

2. Name three specific changes that you will try to apply personally within the scope of your job, based on what you have learned. Do you see barriers to their implementation?

- Enhance volcanic awareness training. (Need subject matter experts and funding to provide the training.)

- Development of a regional volcano-hazard mitigation plan.

- Coordinate with local jurisdictions a communitypreparedness education campaign regarding vol- 
cano hazards. (Need support of local jurisdiction to commit resources and local voluntary organizations active in disasters (VOADS).)

3. Identify three key recommendations you would like to make to management within your agency to more effectively deal with a future volcano crisis at Long Valley. In other words, what changes would you like to see in the status quo?

- Dedicated trained staff who become more subjectmatter experts within the Cal OES region to support internal staff and external stakeholders in mitigation/ planning for a volcanic event in Long Valley.

- Develop a list of best practices in coordination and response to a volcanic event.

- Conduct a volcanic-hazard exercise to identify areas of opportunity to improve response to such an event.

4. After seeing the situation in Chile, have your views on volcano hazards in California changed?

- I am much more knowledgeable of the dangers and impacts of a volcanic eruption and the preparedness that is needed at the local level to ensure the protection of life and property. I don't think people who live near volcanic areas realize the serious impacts due to the low level of activity in California versus other volcanic regions.

5. How could this exchange experience be improved? For example, please comment on logistics, number of delegates and expertise represented, delegate interactions, previsit briefings, or anything else?

- Previsit briefings would be helpful versus waiting a few days before the trip to review logistics.

- Also, an online volcanic course or awareness course should be a prerequisite for participating in the exchange.

- The days were too long in Chile making it difficult to be effective in end-of-the-day discussions to get the full value of the presentations.

- End-of-the-day delegate briefings would be helpful to ensure we are capturing key lessons learned for the day to report back to our respective agencies.

\section{U.S. Delegate Response 4}

1. What key insights have you gained from the visit to Chile (from a broad perspective)?

- First, an appreciation for the organizational structure we have to respond to State and (or) national emer- gencies. Second, the importance of communication and sharing of information before, during, and after an emergency/evacuation. Finally, the importance of developing local resources and capacity.

2. Name three specific changes that you will try to apply personally within the scope of your job, based on what you have learned. Do you see barriers to their implementation?

- In regard to volcanoes in the United States or more specifically California, it is important to start the dialog and share information with local resources. To do that it will be important to coordinate with local entities and work together on a scenario that involves an eruption and evacuation. Develop information and contacts for addressing an emergency in this landscape. I think the biggest barrier is that people don't necessarily want to admit that they may live within a hazard zone.

3. Identify three key recommendations you would like to make to management within your agency to more effectively deal with a future volcano crisis at Long Valley. In other words, what changes would you like to see in the status quo?

- Develop the network of contacts, as well as roles and responsibilities, to be PREPARED for a future volcano crisis.

- Share information on what is being done now, what information is being gathered and how will that be used.

- Use the ICS as a tool for emergency management.

4. After seeing the situation in Chile, have your views on volcano hazards in California changed?

- I think what struck me was the timeframes involved with volcano hazards. The volcanic eruption in Chaitén was relatively long ago and to see the conditions of that community now was rather sobering. Oftentimes we work with wildland fires that are generally not so long-lasting in duration and with weather conditions the hazards may be reduced. I was struck by the fact that volcano hazards are ALWAYS there and evacuations may be ongoing for quite some time. All of that made me think that we are unprepared for an eruption.

5. How could this exchange experience be improved? For example, please comment on logistics, number of delegates and expertise represented, delegate interactions, previsit briefings, or anything else?

- I think the briefings and all the meetings were very good. Initially I had trouble grasping the organiza- 
tional structure but that became clear through the meetings and discussions. I think this particular exchange covered the gamut in terms of all the various levels of organization, which was very good. I think moving down from the national to the local level provided insightful discussions. I think it really went very well, and I can't think of anything I would recommend changing.

\section{U.S. Delegate Response 5}

1. What key insights have you gained from the visit to Chile (from a broad perspective)?

- Planning for geologic hazards and response to natural disasters is highly dependent on the overall system of government. The highly centralized planning and emergency-response system in Chile may make adoption of procedures from the U.S. system very difficult. Natural-hazard information in Chile is highly fragmented among government departments and academic institutions. They may be able to learn from the example of California, where the Caltech, Berkeley, USGS, and CGS networks have been melded into the California Integrated Seismic Network-with encouragement funding from Cal OES.

2. Name three specific changes that you will try to apply personally within the scope of your job, based on what you have learned. Do you see barriers to their implementation?

- At this point, I don't see a need for changes within the scope of my job. Possibly after the second half of the exchange in September.

3. Identify three key recommendations you would like to make to management within your agency to more effectively deal with a future volcano crisis at Long Valley. In other words, what changes would you like to see in the status quo?

- At this point I don't see a need for changes in the status quo regarding my agency's planning for events at Long Valley - maybe after we visit and talk about planning, monitoring, and consequences of specific events there. I do see a need for detailed descriptions of the possible consequences of different types of volcanic eruptions at Long Valley. Such "planning scenarios" are a key means for communicating science to emergency managers.

4. After seeing the situation in Chile, have your views on volcano hazards in California changed?

- Even though I still view volcano hazards as a relatively low-level threat to California (compared to earthquakes, flooding, and landslides) the range and severity of volcano hazards needs to be effectively communicated to emergency managers.

5. How could this exchange experience be improved? For example, please comment on logistics, number of delegates and expertise represented, delegate interactions, previsit briefings, or anything else?

- I'm very impressed that this exchange, set up by volcanologists, decided to focus on emergency response and recovery. That focus, and the representation of emergency-response professionals, seems to be where the most improvement can be made. We saw pretty vividly in Chile that the communication between scientists, emergency managers, and the public needs to be worked on and improved. The interaction between the U.S. and Chilean emergency managers seemed to go really well and has the most potential for positive change in the way Chileans organize their emergency response.

- There seems to be good representation from regional and local government among the Chilean delegates, but no representative of local government or emergency-response agencies among the U.S. delegates.

- The logistics of the Chile trip worked well (although the drive from Temuco to Puerto Varas took more time and was less interesting/scenic than hoped). My only regret is that I didn't learn more of the government structure of Chile before going. My answers to the pretrip questionnaire assumed a California-like system, where planning and development decisions are made at the local level. Clearly, some major decisions in Chile are supposed to be made in Santiago, but I'm still not sure of the roles of regional and provincial government.

\section{U.S. Delegate Response 6}

1. What key insights have you gained from the visit to Chile (from a broad perspective)?

- I learned that the emergency-response process in Chile is similar to California's, with some exceptions.

- Chile faces some of the same challenges that we have also faced in the past, such as communicating and coordinating effectively with our local partners and dealing with politics during emergency responses.

2. Name three specific changes that you will try to apply personally within the scope of your job, based on what 
you have learned. Do you see barriers to their implementation?

- I feel that we need more focus and awareness of the volcano threats that exist here in California. I have been working here for 8 years and was not aware of the high threat potential volcanoes that exist in our State and can also say that many in our department are also not aware of these threats. I will be recommending to our deputy director of preparedness that Cal OES needs to make the department more aware of volcanic threats and perhaps have an exercise on how we would respond to a volcanic eruption.

3. Identify three key recommendations you would like to make to management within your agency to more effectively deal with a future volcano crisis at Long Valley. In other words, what changes would you like to see in the status quo?

- (1) Finalize efforts to develop a volcano-hazard response plan, (2) raise awareness of the need for increased coordination among agencies, and (3) exercise the plan once developed.

- Of course, volcano planning requires available staff time and a budget that competes with earthquake preparedness and tsunami planning as an agency priority.

4. After seeing the situation in Chile, have your views on volcano hazards in California changed?

- Yes, my views have changed significantly. I was not aware of the volcano threats that we face here in California. I think that our department needs to increase awareness on preparing and responding to this threat. Schools and the public that live within volcano-hazard areas should be made aware of the dangers of a volcanic eruption, have a preparedness plan, and practice their plan on an ongoing basis.

5. How could this exchange experience be improved? For example, please comment on logistics, number of delegates and expertise represented, delegate interactions, previsit briefings, or anything else?

- Overall, the exchange experience and coordination was great. The number of delegates was adequate, and you brought expertise from various disciplines and scheduled meetings with our appropriate counterparts. I learned a great deal from this experience and it reinforced that our mutual aid system in California is great. I also think they would benefit if we provided them with a briefing or presentation on our specific discipline, such as in my case, emergencyresponse process or California's mutual-aid system. This way, representatives in Chile would have the opportunity to learn from our system. In regards to logistics, I would recommend hiring or leasing the delegation's own van and driver.

\section{U.S. Delegate Response 7}

1. What key insights have you gained from the visit to Chile (from a broad perspective)?

- The trip to Chile made me more aware and gave me some understanding of the potential for volcanic activity in the Long Valley Caldera and risks and hazards that could be present if to occur.

2. Name three specific changes that you will try to apply personally within the scope of your job, based on what you have learned. Do you see barriers to their implementation?

- First would be to enlighten my colleagues in incident management of the potential risks and hazards associated and the potential reality of an incident locally.

- Second is to learn what precautions and preplanning has been implemented here [Long Valley] in the past, revisit those plans, and update them and spread awareness.

- Third, I have thought a lot about spreading awareness of different types of natural-disaster scenarios and what is the best way to get that word out to residences, transient visitors, and others effectively.

3. Identify three key recommendations you would like to make to management within your agency to more effectively deal with a future volcano crisis at Long Valley. In other words, what changes would you like to see in the status quo?

- That's a tough one. Awareness as stated is one. We cannot focus just on volcanoes but should include all natural disasters. We live with fire every year and still do not have a message that really gets to everyone with all the (1) risks and hazards that can be mitigated to prevent wildfires or (2) procedures to follow in the event of a natural disaster (for example, evacuation routes).

- I believe that the ICS that is used by emergency responders works and would work in the event of an eruption within Long Valley Caldera.

4. After seeing the situation in Chile, have your views on volcano hazards in California changed?

- I learned a lot about the hazards volcanoes can exhibit, which I did not know before. So instead of changing my view, it opened up a new vista. 
5. How could this exchange experience be improved? For example, please comment on logistics, number of delegates and expertise represented, delegate interactions, previsit briefings, or anything else?

- I don't have much here. I thought the logistics went well, and I cannot complain about accommodations. I thought the quality of subject matter experts from the Chilean side was adequate. The U.S. delegate group was engaged and meddled well together. I felt from previsit briefings and correspondence that I was prepared for the trip.

- It was difficult (1) from an emergency-responder point of view and (2) trying to learn the Chilean command system and having meaningful conversations without a translator versed in the subject.

\section{U.S. Delegate Response 8}

1. What key insights have you gained from the visit to Chile (from a broad perspective)?

- Chile faces many of the same hazards that Baja California, California, Oregon, and Washington have to prepare for. The Chilean emergency-management programs and hazard-monitoring networks in place are well developed. Disseminating pertinent information to the public is difficult, owing to access to communities and the time constraints placed on management and monitoring organizations. Each community at the base of a given volcano will have similar yet different hazards so each management plan has to be customized individually. I do not understand the separation of the tectonic seismic network (and not registering events less than magnitude 3) from the volcanic seismic network. Small volcanic earthquakes may not reach all distant seismometers, but some might, especially if it is a larger volcanic event. Similarly, a tectonic event may have an effect on a volcanic center.

2. Name three specific changes that you will try to apply personally within the scope of your job, based on what you have learned. Do you see barriers to their implementation?

- Better awareness and education to the public servants that greet visitors upon arrival, including welcome center staff, USFS staff, and Devils Postpile National Monument staff.

- Implement public-outreach programs for the school systems and summer interpretive programs during the busy summer season. Work with local schools to get information to non-English-speaking populations (mostly Spanish).
- Some in Mono County may not like to accept that several communities live on the edge of potentially active volcanic centers.

3. Identify three key recommendations you would like to make to management within your agency to more effectively deal with a future volcano crisis at Long Valley. In other words, what changes would you like to see in the status quo?

- Review and update the emergency-response plan. Not necessarily updating sections on seismic activity but updating information on key USGS officials, emergency responders, and evacuation plans.

- Remind emergency managers, public-land managers, and communities that volcano hazards are a real potential in California and dangerous conditions can develop without an actual eruption.

- Review what is on the USGS, FEMA, Cal OES information and make sure people know it is available. Do a presentation for the local Community Emergency Response Team (CERT).

4. After seeing the situation in Chile, have your views on volcano hazards in California changed?

- California has several volcanic centers that the public and emergency managers are unaware of or have not had to respond to. Emergency managers are more accustomed to dealing with hazards like earthquakes, floods, fires, and other weather related events. The lack of recent volcanic activity in the "lower 48" [States] has put volcano hazards more on the back burner. It is better to be prepared for a nonevent than to be caught off guard.

5. How could this exchange experience be improved? For example, please comment on logistics, number of delegates and expertise represented, delegate interactions, previsit briefings, or anything else?

- The presentations were well done and informative. The schedule was possibly a bit too busy with little time for reflection or to catch up with the information given at a given presentation(s). As an interpreter, it would have been beneficial to have had a chance to review presentations before interpreting them, but I understand that is not always possible.

- I have been impressed by "nuevas noticias" on the Web page related to education and outreach that include a new video in Spanish "what is a volcano," a public meeting in Puerto Montt about Calbuco Volcano, ironically a week or so before the eruption. 


\section{U.S. Delegate Response 9}

1. What key insights have you gained from the visit to Chile (from a broad perspective)?

- I really enjoyed the time in Chaitén and speaking with local officials and private citizens about the 2008 evacuation and life today in the community. I thought the discussion about the evacuations, the sheltering, and the current evolution of the Chaitén community was the highlight of the trip. As for key insights in Chaitén, I guess it was learning about the parallel efforts of public officials and community members attempting to recover from the eruption. They were often complementary but sometimes conflicting on the vision for the community and at the business/household level. I also enjoyed the time in Santiago/Temuco and seeing their monitoring and operations. One insight from the time in Santiago is that [Chile's] USGS and FEMA equivalents seem to be well connected and coordinated. It seems they work very well together.

2. Name three specific changes that you will try to apply personally within the scope of your job, based on what you have learned. Do you see barriers to their implementation?

- I enjoyed the discussion with the ranger from Pumalín Park. I will now try to look more into park issues, not just visitors but also ecosystem goods and services represented by the parks. I am also intrigued by the sheltering issues during evacuations and how to quantify/map some of those quality-of-life and socioeconomic issues. Perhaps look at neighboring communities to understand evacuee capacity when we do vulnerability assessments. We could focus on indirect impacts to neighboring communities, instead of just looking at direct impacts for communities in hazard zones. A similar issue occurred with Hurricane Katrina in that many communities (as far away as Atlanta) were impacted because of refugees streaming in and overwhelming local services. I imagine the same could happen with an evacuation from a U.S. volcano.

3. Identify three key recommendations you would like to make to management within your agency to more effectively deal with a future volcano crisis at Long Valley. In other words, what changes would you like to see in the status quo?

- Hard to say, because I'm not in the USGS Volcano Hazards Program. However, I do look forward to continuing to work with you all at CVO and CalVO on issues of societal vulnerability to volcano hazards. So many opportunities in the near future. As for changes in the status quo at the USGS, it would be great to see volcano vulnerability research become even more recognized at the program level, instead of only individual efforts led by passionate and supportive volcanologists. Much could be done at the program level in terms of analysis (for example, national assessment of population exposure to volcano hazards) that could complement National Volcano Early Warning System (NVEWS) and support local efforts with external partners. Related, there could be community/practitioner-based vulnerability and needs assessments to gauge primary issues at each volcano. They would involve holding meetings with key practitioners to understand key vulnerabilities in various sectors that would help inform the type of warnings and hazard assessments that may be needed locally.

4. After seeing the situation in Chile, have your views on volcano hazards in California changed?

- My views haven't changed, just confirmed that California has volcano hazards and there is much to be done.

5. How could this exchange experience be improved? For example, please comment on logistics, number of delegates and expertise represented, delegate interactions, previsit briefings, or anything else?

- I thought the exchange went very well, including translations and logistics. I was very happy with how the trip played out and enjoyed the emphasis on how public officials plan for, respond to, and recover from volcano hazards. Although we don't have any California communities recovering from a catastrophic volcano eruption, I hope the California part of the exchange will focus as well on the emergencymanagement aspects of the volcano hazards, perhaps even do a tabletop exercise with officials and a practitioner-based vulnerability assessment (that is, not huge community meeting, perhaps 20 folks at most).

- I thought the number of delegates was great. As for improvements in hindsight, it would have been nice to have a county emergency manager represented in the group, perhaps from Shasta or Mammoth. also perhaps someone from FEMA Region IX. As for interactions in Chile, it would have been nice to have more time speaking one on one with the community members in Villarrica, who had just experienced the volcano eruptions (two weeks before) so their experiences with understanding and acting upon volcano hazards information is priceless. As for delegate interactions, it may have been nice to give everyone in the U.S. delegation a chance to present/discuss what they do before going down there (for example, 
webex back here in the States) or perhaps on the first day in Chile. People's expertise and backgrounds emerged slowly over the trip, but it would have been nice to have a better handle before going to maximize discussions. The bios were nice but didn't really capture people's expertise.

\section{Chilean Delegate Responses to California Posttrip Questionnaire}

\section{Chilean Delegate Response 1}

1. What key ideas that you have obtained from the visit to California (from a broad perspective)? ¿Qué ideas clave que has obtenido de la visita a California (desde una perspectiva amplia)?

- El conocimiento geológico es fundamental para la correcta definición de escenarios futuros y su potencial mitigación. Geological knowledge is essential for the correct definition of future scenarios and potential mitigation.

- -La comunidad debe ser continuamente educada con respecto a los peligros que representan su entorno y en conocimiento de las medidas que se deben seguir en caso de una emergencia. The community must be continually educated about the dangers of their environment and knowledge of measures to be followed in case of an emergency.

- La estructura y organización del manejo de crisis deben estar definidas y consensuadas entre todos los actores relevantes en forma previa a un evento natural catastrófico, independiente de su naturaleza. The structure and organization of crisis management should be defined and agreed upon by all relevant stakeholders in advance of a catastrophic natural event, independent of its nature.

2. Identify three specific changes that you are going to try applying personally within the scope of your work, based on what you've learned. Do you see barriers to implementation? Identificar tres cambios específicos que vas a tratar de solicitar personalmente en el ámbito de tu trabajo, con base en lo que has aprendido. ¿Ves barreras para su implementación?

- Mayor contacto con las comunidades locales en los distintos lugares donde realizamos estudios geológicos. Increased contact with local communities in various places where we conduct geological studies.

- Orientar la manera de comunicación escrita hacia una mejor comprensión para el público no-técnico, evitando términos que a veces resultan demasiado específicos. Guide the way of written communication to a better understanding for a nontechnical audience, avoiding terms that are sometimes too specific.

- Impulsar la interacción entre las distintas agencias relacionados a la evaluación y manejo de crisis mediante seminarios y reuniones periódicas. Encourage interaction among the different agencies related to the assessment and crisis management through seminars and regular meetings.

3. Are there any recommendations you would make to management within your agency to deal more effectively with future volcanic crisis in Chile? In other words, what changes would you like to see in the status quo? ¿Hay recomendaciones que te gustaría hacer a la gestión dentro de tu agencia para hacer frente de manera más eficaz con una futura crisis volcánica en Chile? En otras palabras, ¿qué cambios te gustaría ver en el status quo?

- Una relación más estrecha con otras instituciones, estableciendo claramente cuáles son las responsabilidades asociadas a las distintas agencias en el país. Dentro de mi propia agencia, recomendaría la creación de un equipo que pudiera establecer las relaciones comunicacionales directamente con los medios y que el flujo de información no dependiera de los geólogos o sismólogos involucrados en la atención de las crisis volcánicas. De esta manera se asegura un mayor enfoque en la evaluación de la crisis y en los requerimientos de las autoridades. $A$ closer relationship with other institutions, clearly stating what responsibilities are associated with each of the various agencies in the country. Within my own agency, I would recommend creating a team that could establish relationships directly with the media, so that the flow of information would not be dependent on geologists and seismologists who are involved in dealing with the volcanic crisis. This would ensure both a greater focus on the assessment of the crisis and greater attention to the requirements of the authorities.

- Finalmente, tal como ocurre en EE.UU., recomendaría la creación de distintos observatorios volcanológicos a lo largo del país, los cuales tengan capacidad independiente para realizar monitoreo volcánico en tiempo real y estudios de peligros. Finally, as in the United States, I would recommend creating different volcanological observatories throughout the country, which have independent ability to perform real-time volcanic monitoring and hazard studies.

4. After seeing the situation in California, have you changed your views on volcanic risk and preparedness in Chile? Después de ver la situación en California, ¿han 
cambiado tus puntos de vista sobre riesgo volcánico y la preparación en Chile?

- En términos de monitoreo volcánico, pienso que estamos a un nivel bastante avanzado en nuestro país. Sin embargo, aún estamos lejos de tener un conocimiento geológico detallado de los volcanes más peligrosos de Chile y el análisis de los peligros asociados, por ejemplo en términos de recurrencia eruptiva o análisis probabilísticos. In terms of volcano monitoring, I think we are at a fairly advanced level in our country. However, we are still far from having a detailed geological knowledge of the most dangerous volcanoes in Chile and analysis of associated risk; for example, in terms of eruptive recurrence or probabilistic analysis.

- Por otra parte, la educación de la población civil y autoridades sobre geología y volcanismo es aún básica y por lo tanto puede afectar negativamente en la preparación de la población ante una crisis. Moreover, the education of the civilian population and authorities on geology and volcanism is still basic and therefore may adversely affect the preparation of the population before a crisis.

5. How can we improve this experience exchange? For example, please comment on the logistics, the number of delegates and experts represented, delegates' interactions, information meetings prior to the visit, or anything else. ¿Cómo podría mejorarse esta experiencia de intercambio? Por ejemplo, por favor comente sobre la logística, el número de delegados y expertos representado, interacciones de delegados, reuniones de información previa a la visita, o cualquier otra cosa.

- En general me pareció una excelente experiencia en términos de logística y del número de participantes, pues lo hace bastante manejable. Creo que la principal dificultad fue la barrera idiomática, pues hay aspectos relevantes que pueden quedar sin discusión por la no comprensión inmediata de los tópicos tratados. Adicionalmente, a las actividades realizadas agregaría al menos una sesión de mesas de trabajo donde fuese posible discutir en grupos pequeños un tema específico en profundidad. Overall, I found it a great experience in terms of logistics and the number of participants; it makes it quite manageable. I think the main difficulty was the language barrier, as there are relevant aspects that may be left without discussion, preventing a full understanding of the topics covered. Additionally, the exchange activities could also include at least one session where it would be possible for small groups to discuss a specific topic in depth.

\section{Chilean Delegate Response 2}

1. What key ideas that you have obtained from the visit to California (from a broad perspective)? ¿Qué ideas clave que has obtenido de la visita a California (desde una perspectiva amplia)?

- Los volcanes activos no solo son aquellos que han hecho una erupción reciente. Active volcanoes are not only those that have had a recent eruption.

- El gran riesgo en que se encuentra la población ubicada en Mammoth Lake y en el Valle de la Gran Caldera. The big risk is for the population located in Mammoth Lakes and in the large caldera.

- Los estudios más recientes relacionados con la gestión de emergencias a través de la información geológica (presentación de Nate). The most recent studies relate emergency management to geological information (Nate [Wood]'s presentation).

- Descentralización del sistema de emergencias y comprender cómo en EEUU el modelo es desde el nivel local hacia arriba. Decentralization of emergency-management system in the United States and understanding how the model works from the local level upwards.

2. Identify three specific changes that you are going to try applying personally within the scope of your work, based on what you've learned. Do you see barriers to implementation? Identificar tres cambios específicos que vas a tratar de solicitar personalmente en el ámbito de tu trabajo, con base en lo que has aprendido. ¿Ves barreras para su implementación?

- Reevaluar la pertinencia de continuar realizando capacitaciones CERT directas a la comunidad o bien a través de una institución especializada que sea agente multiplicador porque la capacidad de ONEMI es baja y el impacto es menor. A través de una institución es más favorable. La principal barrera es el presupuesto de la institución. Reevaluate the relevance of CERT teams in helping communities versus help through a specialized institution that could be a [an assistance] multiplier, because [currently] ONEMI's capacity is low and its impact is minor. In general, the potential of an institution is greater. The main barrier is the budget of the institution.

- Generar e impulsar campañas de difusión pertinentes a cómo actuar en emergencias volcánicas, actualizando las ya existentes. Generate and promote campaigns of information dissemination relevant to how to act in volcanic emergencies, updating existing ones. 
- Aumentar el número de profesionales especializados en SCI, el cual permitirá poder desenvolverse en emergencias en terreno como también comprender mejor la gestión de estas en el gabinete. Increase the number of specialized professionals in SCI, who would be able to function in the field during emergencies and also look at how to better manage these personnel.

3. Are there any recommendations you would make to management within your agency to deal more effectively with future volcanic crisis in Chile? In other words, what changes would you like to see in the status quo? ¿Hay recomendaciones que te gustaría hacer a la gestión dentro de tu agencia para hacer frente de manera más eficaz con una futura crisis volcánica en Chile? En otras palabras, ¿qué cambios te gustaría ver en el status quo?

- Potenciar las campañas de difusión de riesgo volcánico. Strengthen [information] campaigns about volcanic risk.

- Trabajar los planes de emergencia y evacuación de cada volcán con la comunidad. Develop emergency and evacuation plans with the local communities for each volcano.

- Generación de estudios de tiempos de evacuación una vez que ya se han realizado los estudios básicos que indican áreas de inundación, vías de evacuación $\mathrm{y}$ puntos de encuentro. Generate studies of [community] evacuation times once basic studies of inundation areas, evacuation route, and meeting points have been completed.

- Diseñar mejor logística en los procesos de evacuación. Design better logistics in the evacuation process.

4. After seeing the situation in California, have you changed your views on volcanic risk and preparedness in Chile? Después de ver la situación en California, ¿han cambiado tus puntos de vista sobre riesgo volcánico y la preparación en Chile?

- Siempre se aprende más, es posible generar mejoras a lo que actualmente se hace. You can always learn more and make improvements to what is currently done.

- A diferencia de California, los volcanes han presentado registros históricos muy antiguos de erupciones y en Chile, no podemos dedicarnos a los volcanes que han tenido erupciones tan antiguas, porque tenemos muchos volcanes activos con erupciones en los últimos años. Desde 2008, Chaitén, PuyehueCordón Caulle, Villarrica, Copahue, Calbuco. Unlike in California, where [many] volcanoes only have records of ancient eruptions, in Chile we cannot dedicate ourselves to the volcanoes that have only had ancient eruptions, because we have so many active volcanoes with recent eruptions. For example, since 2008, Chaitén, Puyehue-Cordón Caulle, Villarrica, Copahue, and Calbuco [Volcanoes have erupted].

5. How can we improve this experience exchange? For example, please comment on the logistics, the number of delegates and experts represented, delegates' interactions, information meetings prior to the visit, or anything else. ¿Cómo podría mejorarse esta experiencia de intercambio? Por ejemplo, por favor comente sobre la logística, el número de delegados y expertos representado, interacciones de delegados, reuniones de información previa a la visita, o cualquier otra cosa.

- La logística preparada fue correcta y muy eficiente. The logistical preparations were correct and very efficient.

- Los tiempos empleados también se cumplieron a la perfección. Use of time available was also fulfilled to perfection.

- Los traslados fueron cómodos y los horarios establecidos también muy correctos. The transfers [between cities] were comfortable and the schedules established were very appropriate.

- Es muy importante poder acercar a los especialistas geólogos con los gestionadores de emergencia, porque la experiencia se hace más enriquecedora. It is very important to bring together geological specialists with the emergency managers because that makes the experience richer.

\section{Chilean Delegate Response 3}

1. What key ideas that you have obtained from the visit to California (from a broad perspective)? ¿Qué ideas clave que has obtenido de la visita a California (desde una perspectiva amplia)?

- Que tenemos mucho que mejorar en las políticas de nuestro país. Estos cambios políticos deben conducir a la integración de diferentes servicios y que se cuente con autoridades conocedoras de las consecuencias del volcanismo y de cómo afrontar medidas para su mitigación hacia la población. We have a lot to improve in the policies of our country. These policy changes should lead to the integration of different services and to knowledgeable authorities who understand the consequences of volcanism and how to carry out mitigation measures for affected populations. 
2. Identify three specific changes that you are going to try applying personally within the scope of your work, based on what you've learned. Do you see barriers to implementation? Identificar tres cambios específicos que vas a tratar de solicitar personalmente en el ámbito de tu trabajo, con base en lo que has aprendido. ¿Ves barreras para su implementación?

- Compartir datos con otras instituciones, para complementar redes de monitoreo en tiempo real. Como barrera veo la falta de disposición de parte de algunos colegas en abrir los datos desde el SERNAGEOMIN. Share data with other institutions, to implement monitoring networks in real time. A barrier I see is the unwillingness of some colleagues to make data available from SERNAGEOMIN.

- Generar difusión del conocimiento hacia la población, mediante talleres, charlas y entrevistas con las personas. No hay barreras, pues es una actividad complementaria al asistir a terreno. Se maneja la idea hace mucho tiempo de desarrollar este tipo de actividades como rol institucional y que no se restrinja a iniciativas personales. Se tratará de retomar esta iniciativa para enmarcarla dentro de los compromisos institucionales. Generate dissemination of knowledge to the population, through workshops, lectures, and interviews with people. There are no barriers, it is a complementary activity to assist [people] on the ground. The idea is handled much time by developing such activities as institutional role ago and not by restricting it to personal initiatives. Advancement of this initiative will need to be framed within [existing] institutional commitments.

- Crear planes de evacuación y atención de crisis volcánica con integrantes de la región (autoridades, fuerzas armadas y demás servicios públicos). La única barrera es la multiplicidad de tareas, por lo que se requiere de mayor personal en la oficina. $\mathrm{Cre}$ ate evacuation plans and volcanic crisis response plans together with the various entities of the region (authorities, armed forces and other public services). The only barrier is the increase in jobs, so it requires more personnel in the office.

3. Are there any recommendations you would make to management within your agency to deal more effectively with future volcanic crisis in Chile? In other words, what changes would you like to see in the status quo? ¿Hay recomendaciones que te gustaría hacer a la gestión dentro de tu agencia para hacer frente de manera más eficaz con una futura crisis volcánica en Chile? En otras palabras, ¿qué cambios te gustaría ver en el status quo?
- Me gustaría participar de las reuniones de toma de decisión respecto a los cambios de alerta y también participar de las discusiones técnicas. Una recomendación a mi institución, entonces, será: la integración de diferentes departamentos y unidades del SERNAGEOMIN a la comprensión del fenómeno volcánico, por ejemplo, la unidad de Geotermia, de Geofísica. I would like to attend meetings for decision making with respect to changes of alert levels and also to participate in the technical discussions. A recommendation to my institution, then, is: the integration of different departments and units of SERNAGEOMIN to improve the understanding of volcanic phenomena, for example, the units Geothermal and Geophysics.

4. After seeing the situation in California, have you changed your views on volcanic risk and preparedness in Chile? Después de ver la situación en California, ¿han cambiado tus puntos de vista sobre riesgo volcánico y la preparación en Chile?

- Me asombra el grado de coordinación y respeto que vi en U.S. Espero contribuir a mejoras en el futuro para mi país. I am amazed at the level of coordination and respect that I saw in United States. I hope to contribute to improvements in the future for my country.

5. How can we improve this experience exchange? For example, please comment on the logistics, the number of delegates and experts represented, delegates' interactions, information meetings prior to the visit, or anything else. ¿Cómo podría mejorarse esta experiencia de intercambio? Por ejemplo, por favor comente sobre la logística, el número de delegados y expertos representado, interacciones de delegados, reuniones de información previa a la visita, o cualquier otra cosa.

- Todo me pareció perfecto. Propondría generar un intercambio donde se incluya también un componente político, para educar a esos funcionarios, que son quienes delinean los caminos sobre los cuales transitamos como sociedad. Everything seemed perfect to me. I would suggest generating an exchange that also includes a political component, in order to educate those public officials who [make decisions affecting how our societies work].

\section{Chilean Delegate Response 4}

1. What key ideas that you have obtained from the visit to California (from a broad perspective)? ¿Qué ideas clave que has obtenido de la visita a California (desde una perspectiva amplia)? 
- Comparto las ideas de Carlos sobre los aprendizajes obtenidos respecto a aspectos culturales, el rol de los comunicadores, quienes son los voceros, la institucionalidad y marco legal y la necesidad de capacitación y entrenamiento a todo nivel. Me permito incluir que llamo mi atención cómo el conocimiento y práctica del mundo científico se acerca a la comunidad, acá en Chile comúnmente lo situamos "afuera", pero me pareció interesante que la gente de USGS participe de la socialización hacia las comunidades, al escucharlos se deja de ver a los volcanes, fallas geológicas, etc. como meros elementos del paisaje o por el contario como terribles amenazas que ponen en peligro a las comunidades, lo son en uno y otro caso por cierto, pero conocer el fenómeno ayuda a entender que conductas humanas son posibles de modificar. Share the ideas of Carlos [Zambrano Fernández]on the lessons learned about cultural aspects, the role of journalists, who are the spokespersons, the institutional and legal framework, and the need for education and training at all levels. I would add that what caught my attention was how knowledge and practice from the scientific world is brought to the community. Here in Chile often we keep [science] "outside" [of our dealings with communities], but I found it interesting that USGS people participate in [communicating hazards information to] communities and that people hear that volcanoes, geologic faults, and other features are [not] mere elements of the landscape but are terrible threats that also endanger the communities in which they occur. However, knowing the phenomenon helps people understand that human behaviors can be changed.

- Esto refuerza la idea de educar, las comunidades aun viviendo al lado de la amenazas volcánicas por dar un ejemplo (como el caso de Mammoth Lake o de Chaiten), pueden ser educadas para conocer esta amenaza y aprender a convivir con ella. This reinforces the idea that communities still living next to the volcanoes can be educated about hazards-for example, in the cases of Mammoth Lake or Chaitén [Volcano]. People can be educated to meet this threat and learn to live with it.

2. Identify three specific changes that you are going to try applying personally within the scope of your work, based on what you've learned. Do you see barriers to implementation? Identificar tres cambios específicos que vas a tratar de solicitar personalmente en el ámbito de tu trabajo, con base en lo que has aprendido. ¿Ves barreras para su implementación?

- Sugerir que OFDA siga apoyando a USGS para continuar este programa porque es valioso generar estos intercambios. Suggest that [USAID-JOFDA continue to support USGS to continue this program because these exchanges are valuable.

- Promover un acercamiento de OFDA y SERNAGEOMIN. Promote a relationship between [USAID-]OFDA and SERNAGOEMIN.

- Promover que la comunidad de Chaiten postule a un programa de small grants de OFDA para apoyarlos en su esfuerzo de educar y preparar a la comunidad frente al riesgo volcánico. Encourage the community of Chaitén to apply for a program of small grants from [USAID-]OFDA to support their effort to educate and prepare the community for the volcanic risk.

3. Are there any recommendations you would make to management within your agency to deal more effectively with future volcanic crisis in Chile? In other words, what changes would you like to see in the status quo? ¿Hay recomendaciones que te gustaría hacer a la gestión dentro de tu agencia para hacer frente de manera más eficaz con una futura crisis volcánica en Chile? En otras palabras, ¿qué cambios te gustaría ver en el status quo?

- Desde el rol que a USAID-OFDA le compete, recomendaría apoyar eventos de diseminación de conocimiento científico y vinculación con comunidades, también si Onemi estuviera de acuerdo, poder entregarles asistencia técnica para optimizar el proceso de alerta temprana desde la perspectiva del trabajo de municipios, esto por las brechas que fueron identificadas durante la visita de campo a Chaiten y Pucon. From the role that USAID-OFDA [plays in being] responsible, I would recommend supporting events [by SERNAGEOMIN?] for dissemination of scientific knowledge to communities, even if ONEMI has already agreed to deliver technical assistance, in order to optimize the efforts of municipalities to provide early warning [during a crisis]. Gaps [in this flow of hazard information] were identified during our field visits to Chaitén and Pucón.

4. After seeing the situation in California, have you changed your views on volcanic risk and preparedness in Chile? Después de ver la situación en California, ¿han cambiado tus puntos de vista sobre riesgo volcánico y la preparación en Chile?

- Si, es evidente que en California hay un proceso institucionalizado de trabajo, disponen de recursos y de un marco legal que faculta a las instituciones a trabajar bajo un mismo estándar (ICS). Yes, it is clear that in California there is an institutionalized process of work, available resources, and a legal framework that empowers institutions to work under one standard (ICS). 
5. How can we improve this experience exchange? For example, please comment on the logistics, the number of delegates and experts represented, delegates' interactions, information meetings prior to the visit, or anything else. ¿Cómo podría mejorarse esta experiencia de intercambio? Por ejemplo, por favor comente sobre la logística, el número de delegados y expertos representado, interacciones de delegados, reuniones de información previa a la visita, o cualquier otra cosa.

- En mi opinión el tamaño y diversidad de los grupos es el correcto, también la duración del programa. Solamente sugiero que en el presupuesto se considere a un traductor profesional, para asi optimizar la comunicación entre los participantes de EEUU $\mathrm{y}$ Chile. In my opinion, the size and diversity of the groups was correct, also the duration of the program. I would only suggest that the budget should have included funds for a professional translator to optimize communication between the participants from the United States and Chile.

\section{Chilean Delegate Response 5}

Preliminary comments. Comentarios Preliminares.

- La pasantía fue una experiencia muy gratificante y muy interesante. El grupo hizo lo suyo también, ya que no siempre se participa en grupos tan colaborativos y amistosos como el que compartimos. Agradezco en forma especial a todos nuestros anfitriones en USA, que nos mostraron un profesionalismo, una calidez y una paciencia envidiable, muchas gracias. También en forma especial a Álvaro, por su consideración al invitarme. The internship was a very rewarding and interesting experience. The [Chilean] group also had this experience, because we seldom interact in ways that are as collaborative and friendly when we meet in groups.

- Si me lo permiten quisiera, a modo de ejercicio muy personal, compartir con ustedes algunas reflexiones sobre lo que vi en este intercambio, tratando de rescatar los conceptos y los desafíos y oportunidades que veo en el horizonte. Muchos de los comentarios que hago pueden sonar muy básicos y comunes, pero creo que la experiencia que tuvimos vale hacer una reflexión y el escribir ayuda. Agradezco desde ya al que se de el tiempo de leer y más aun si decide comentar. If I may, I would like, as a very personal exercise, to share with you some thoughts about what I saw in this exchange, while trying to extract the concepts, challenges, and opportunities that I see on the horizon [for the United States and Chile].
Many of the comments I am making may sound very basic and ordinary, but I think I can better reflect on our experience by writing. Thank you for reading this and for your thoughts if you choose to comment.

- Aspectos culturales y políticos. Cultural and political aspects:

- Es indiscutible que existe una gran diferencia política y cultural (cómo razonamos y actuamos como sociedad) entre USA y Chile, por lo que es obvio que no es posible "copiar" el sistema de manejo de emergencias que el Estado de California tiene implementado, tampoco en Chile es posible contar con los presupuestos con que ellos disponen, que nos parecen enormes. Sin embargo, creo que es posible rescatar los conceptos y trabajo sobre puntos críticos que vimos en nuestro intercambio. It is indisputable that there is great political and cultural difference (how we reason and act as a society) between the U.S.A. and Chile, so obviously it is not possible to "copy" the emergency-management system that the State of California has implemented, nor in Chile is it possible to have the budgets they have, which seem enormous. However, I think it is possible to extract the concepts and work on critical points that we saw on our exchange.

- Trabajo con los medios de comunicación y comunicadores sociales: Fue curioso conocer que los periodistas y comunicadores sociales de los Medios juegan en USA un papel clave en el manejo de emergencias, esto se da también en Chile. Resulta entonces que en Chile, al igual que en USA, debiésemos trabajar sobre los medios y comunicadores sociales en pro de que entiendan que su rol es determinante y pueden transformarse en un agente clave para un correcto manejo de la emergencia en una comunidad, creo que dándoles el reconocimiento y la importancia adecuada ellos podrían alinearse. Quizás debiesen ser incluidos en futuros cursos respecto de estos temas, ya que esto no redundaría en importantes costos de operación, también, tiene relación con que cada encargado de emergencia y/o alcalde se decida a trabajar esto en forma metódica y constante. $I$ work with the media and journalists - It was interesting to recognize that journalists and the media in the U.S.A. play a key role in emergency management; this also occurs in Chile. It follows that in Chile, as in the U.S.A., we should work with the media and journalists (and give them training?), while recognizing that their roles are crucial 
and they can become key players (partners?) in the effective management of an emergency in a community. I think giving proper recognition and importance to them could promote alignment of interests. Maybe they should be included in future emergency-management courses, as this would not result in significant operating costs, but every emergency manager and (or) mayor has to decide how to work this out in a consistent way.

- Informantes locales y leguajes comunes: En la eventualidad de una emergencia, ya sea para contar con información temprana asertiva y precisa o por que la magnitud de la emergencia tiene caídos los mecanismos formales y habituales de comunicación, creo que al igual que con los medios de comunicación, se podría capacitar en materias de emergencias a los presidentes de juntas de vecinos, clubes deportivos, etc. Esto podría ayudar a implementar un lenguaje en común y universal para expresar, informar y evaluar preliminarmente una emergencia. Local informants speaking a common language - As with the media, I think you could provide training in emergency procedures to the presidents of neighborhood associations, sports clubs, [and other organizations], so that in the event of an emergency, they could communicate early information clearly and accurately, and communities wouldn't have to rely on the usual formal communication mechanisms.

- Credibilidad, vocería y oportunidad: Cuando te aproximas y trabajas en forma habitual con la comunidad, cumpliendo los compromisos adquiridos vas ganando credibilidad, que como vimos, es un factor clave en el manejo de emergencias. Al involucrar a las juntas de vecinos, clubes deportivos, etc. en capacitaciones de manejo de emergencias, se les hace parte del sistema y por lo tanto de la credibilidad y del entendimiento del proceso. Credibility, spokespeople, and opportunityWhen you approach and routinely work with the community, fulfilling commitments made to them, you gain credibility, as we saw [working with a community in Parque Pumalin]. That credibility is a key factor in handling emergencies. By involving neighborhood associations, sports clubs, and others in emergency-management training, they are made part of the system by virtue of that credibility and understanding of the process.

- Una gran diferencia que vimos entre Chile y USA es el manejo de la vocería en la emergencia. Por lo poco que he visto y lo que escuché de ustedes, en Chile es habitual que el Alcalde sea el que haga la vocería, dada la responsabilidad que tiene en sobre el territorio y recursos, también, porque es una vitrina política. Sin embargo, esta vocería puede transformarse en un salvavidas de plomo si el manejo de la emergencia resulta mal o no se lleva la comunicación en forma asertiva y adecuada. Resulta clave, creo, que el COE (técnico) [Comité de Operaciones de Emergencia] otorgue al Alcalde esta atribución, pero sea el COE el que elabore los comunicados para que el Alcalde pueda "lucirse" y deje actuar a los equipos técnicos en la evaluación y propuestas de intervención. One big difference we saw between Chile and the U.S.A. is in the management of the official voice in managing the emergency. From what little I've seen and what I heard from you, in Chile it is customary that the mayor is the official spokesperson, given the responsibility he/she has over [the local] territory and resources, and also because it is politically advantageous for such local officials [to take this role]. However, this responsibility can be transformed to a "lead lifejacket" if the handling of the emergency is bad [ineffective] or if the [warning or other hazard information] is not accurately or appropriately communicated. It is key, I believe that technically the COE [Emergency Operations Committee] gives this authority to the mayor. However, the COE must prepare the information releases for the mayor, so that he/she can make public statements that are accurate with regard to the [hazard] assessment and intervention proposals.

- Quizás es posible desde ONEMI definir algunas comunas "pilotos" en que los Alcaldes están dispuestos a probar este método, luego sistematizar la experiencia y socializarla en otras comunas y dentro del mundo político (parlamento), convocando a más Alcaldes a sumarse al método. Para incentivar este proceder, ONEMI, podría disponer de algunos fondos que se otorgarían sólo a aquellas comunas que estén dispuestas a esto, por ejemplo para hacer capacitaciones (no sé si es posible esto en términos legales, pero sospecho que sí). A otra escala el comando de emergencias en USA hace algo similar y me pareció una buena idea. Perhaps it would be possible for ONEMI to define some "pilot" communities in which the mayors would be willing to try this approach [and accept this responsibility]. Then this approach could be systematized for wider application in other communities, and political leaders (parliament) could 
call for more mayors to participate. To encourage this approach, ONEMI could be granted additional funds that would be released only to those municipalities willing to do this [more localized emergency preparation]; for example, for training (not sure if this is possible in legal terms, but I suspect so). On another scale, emergency command in the U.S.A. does something similar, and it seemed a good idea.

- Quizás en este tema hay un gran desafío para el personal de prensa de ONEMI y SERNAGEOMIN. ¿Han participado ellos de este tipo de actividades, como la que compartimos nosotros en esta oportunidad? Perhaps this issue is a major challenge for the outreach staff in ONEMI and SERNAGEOMIN. Have they participated in such activities previously, such as we have shared this time [on the exchange]?

- Cambio en la institucionalidad: Desconozco mayores detalles de cómo ésta opera en Chile y cómo está definida la institucionalidad para el manejo de emergencias, lo que sí sé es que escuché de ustedes muchas críticas y un permanente sentimiento de traba. Por otro lado el manejo de las emergencias tiene un gran impacto en la evaluación de la ciudadanía para con sus gobiernos (locales, regionales, nacionales). Un buen manejo integrado (credibilidad, comunicación, respuesta, nivel técnico, integración de comunidad, flujo de la información en una doble dirección) puede resultar en un trampolín político de primer nivel. Lo contrario puede resultar en un salto al vacío. Conversando con una colega del grupo, comenté a ella que sería interesante poder identificar en el parlamento a algún Diputado y/o Senador que le interesen estos temas y vea en ello la potencialidad política que tiene. En un país como Chile, carente de discurso político y de propuestas, algo como esto puede transformarse para un político en algo distintivo e interesante para su región. Ese o esos políticos dispuestos a trabajar sobre esto debieran ser incluidos en intercambios y talleres de trabajo en estas materias. Institutional change-I do not know details of how emergency management operates in Chile or how it is structured in institutional frameworks, but what I do know is that I have heard a lot of criticism [about how emergency management works in Chile] and that there is a deep feeling that [emergency-management efforts] are often more obstructive than helpful. Moreover, emergency management has a great impact on citizens'opinions of their governments (local, regional, national). A good integrated management [system] ([having] credibility, communication, accountability, technical [competence], and integration of the community through a two-way flow of information) can result in a political giveand-take of the first order. Otherwise it can be a political catastrophe. In talking with a colleague in our group, I mentioned to her that it would be interesting to identify in the parliament any deputy or senator who might be interested in these issues and to see what political potential such a connection might have. In a country like Chile, where political discourse and proposals are generally lacking, a motivated politician whose views have been transformed could do some interesting things for his/her region. Politicians willing to work on this [vertical integration of emergency management] should be included in exchanges and workshops covering these topics.

- Sin duda los Alcaldes que decidan adentrarse en estas materias y sinceramente trabajar en mejorar sus manejos de emergencias podrían ayudar a encontrar a los políticos antes mencionados, al fin y al cabo, son generalmente miembros de colectividades políticas y pueden sondear en mejor forma que un chileno común y corriente. Certainly the mayors who commit to making such changes and are sincerely working on improving emergency management in their areas could help find such interested politicians, because at the end of the day, they are also members of political communities and can fathom [and present] the issues better than an ordinary Chilean.

- Capacitación, entrenamiento, profesionalismo: Sin duda la capacitación en estas materias mejorará nuestro entendimiento y nuestro accionar. Influenciar sobre paradigmas hasta lograr el cambio es un largo camino que a veces parase no avanzar. Escuché en nuestro viaje algunos comentarios como por ejemplo que se ha invitado a numerosas personas, jefes de servicios, etc a capacitaciones sobre el tema y no se ven cambios... se debe insistir en ello, tanto va el cántaro al agua que al final se rompe, de todas maneras no sería un error si las personas que toman la decisión de quienes asisten a un curso se toman un trabajo/tiempo extra y analizan cuales son los nodos críticos en la institucionalidad y enfocan sus recursos en ello, a la vez de enfocar capacitaciones a nivel de base (masa). Capacity, training, professionalism-Certainly training enhances our understanding and our actions. To have influence on existing paradigms and to achieve change is a long-term commitment, and sometimes progress doesn't seem evident. I heard some comments on our journey that invitations for training classes had been sent to several agency directors but that no involvement from them had been seen ... but 
their involvement should be insisted on. However, people who decide to take a training course should put in extra time to analyze the critical nodes, focus resources on those issues, and get training to the grassroots level.

- Parque Pumalín: La pasantía ha sido muy interesante y aclaradora en cuanto a cómo enfrentar distintas situaciones bajo un mismo concepto de comando de emergencias. En Pumalín desarrollé protocolos de emergencia muy simples, pero todos tienen un mismo problema y, en cierta forma, son reflejo de nuestra sociedad y de nuestros paradigmas. También en Pumalín, la decisión de qué hacer y cómo proceder la concentraba en el jefe de cada área y luego en la administración general. La idea de un comando de gestión me parece lejos mejor. Aunque, en cierto modo, para emergencias grandes e importantes para nuestra escala ha operado una especie de comando, conformado por la administración general y colegas de la oficina central en Puerto Varas, entre estas personas en conjunto se van tomando las decisiones que son comunicadas al público por sólo una persona. Con esta pasantía me resulta mucho más claro ver de mejor forma el cómo organizar una respuesta. Las recomendaciones de Kristin me ayudaron a definir cuantos ejercicios de simulación son necesarios al año para un equipo como el de Pumalín. También, soluciones tan simples como las tarjetas individuales con lo básico del protocolo en ellas me ha sido de gran ayuda. Para Pumalín sería muy útil y creo que para el gobierno local y los encargados de emergencias del gobierno también, dada la magnitud geográfica que tiene el Parque, el conectar a Pumalín con ONEMI, ser uno de los informantes capacita- dos y a la vez recibir a tiempo alertas que puedan ayudarnos a manejar, por ejemplo en verano, posible situaciones de emergencia con los miles de visitantes que tenemos dentro. Pumalin Park-The exchange was very interesting and clarifying as to how to deal with different situations under the unified command concept for handling emergencies. In Pumalin, I developed very simple emergency protocols, but they all have the same problem and, in a way, are a reflection of our society and of our paradigms. Also in Pumalin, the decisions for what to do and how to proceed are limited to the heads of each area and then [above them] in the general administration. The idea of a unified command seems to me far better. Although, in a way, for emergencies that are large and important to us, we have operated under a kind of command, which consists of the general administration and colleagues from the headquarters in Puerto Varas. Decisions reached by these people as a whole are communicated to the public by only one spokesperson. With this internship, I have gotten a much clearer view of how best to organize an [emergency] response. Kristin[Kirschner]'s recommendations helped me define how simulation exercises are needed each year for a team like ours at Pumalin. Also, solutions as simple as individual cards with the basics of the protocol printed on them I found very helpful. At Pumalin, given the huge size of the park, it would be very useful for the local government and emergency managers from the national government to connect Pumalin officially with ONEMI, so that the park would directly receive official alerts. This would greatly help park management, particularly in summer when possible emergency situations could involve thousands of park visitors. 
Menlo Park Publishing Service Center, California

Manuscript approval date May 15, 2017

Edited by James W. Hendley II

Design and layout by Suzanne C. Roberts 
Back cover. An explosive eruptive pulse from Chaitén Volcano, Chile, viewed from town of Chaitén during the first week of its eruption in May 2008. (Photograph courtesy of Servicio Nacional de Geología y Minería de Chile.) 


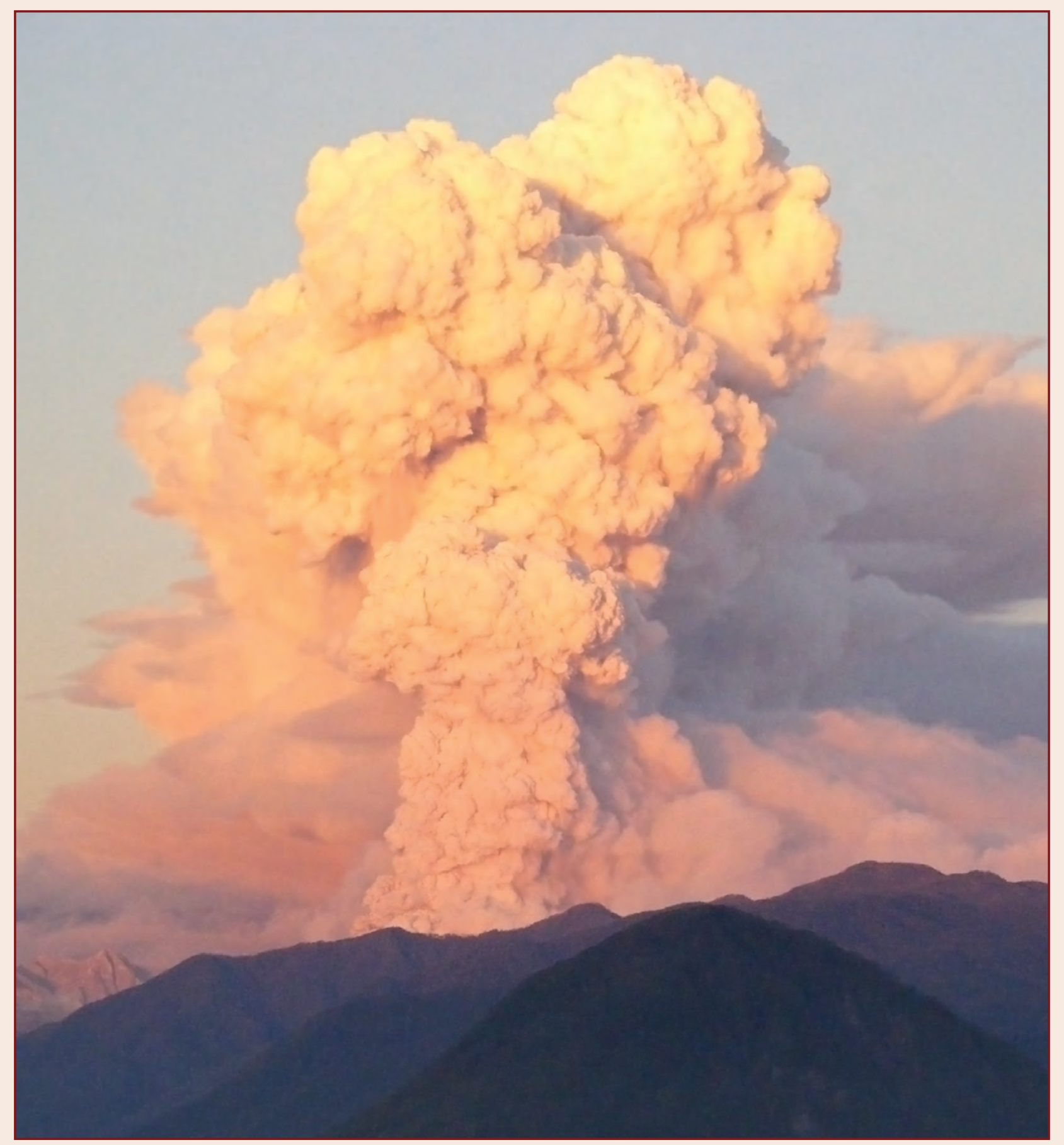

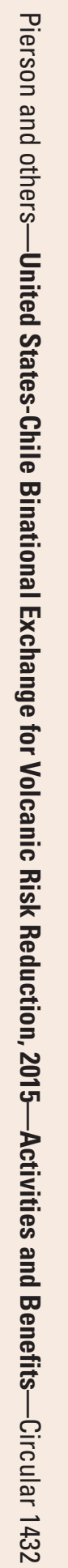

